\title{
The Commercial Lease: Property or Contract?
}

\section{JASON BROCK AND JIM PHILLIPS}

The commercial lease has historically been treated as a conveyance of an interest in land which creates a property-based relationship between the lessor and lessee, despite the fact that the relationship is created by contract and could be seen as a contract for the ongoing use of the land. Some Canadian cases, however, have applied "partial contractualization" - using both property and contract rules and concepts to interpret leases. The article examines the historical development of the lease and its treatment in Canadian courts, as well as in other common law courts. The authors argue that the property/contract hybrid should be eliminated in favour of "complete contractualization" - using pure contract principles to interpret the commercial lease. The article points out how contract principles would serve the parties to the lease just as well, or better, than property principles and offers solutions for the anticipated problem area of security of tenure for the tenant.
Historiquement, le bail commercial est traité comme un transport d'intérèts sur des terres donnant lieu à une relation basée sur la propriété entre le bailleur et le locataire, et ce, bien que la relation provienne d'un contrat et pourrait ètre vue comme tel aux fins de l'utilisation continue des terres. Or, dans certaines causes juridiques au Canada, on a eu recours à la " contractualisation partielle ", utilisant les règles et concepts du droit des biens et de contrat pour interpréter les baux. Dans cet article, les auteurs examinent l'évolution historique du bail et la manière dont il a été traité par les tribunaux canadiens et autres tribunaux de Common Law. Les auteurs estiment que le droit hybride des biens et de contrat devrait être éliminé au profit d'une " contractualisation complète "utilisant lesprincipes du droit de contrat pur pour interpréter un bail commercial. L'article fait ressortir comment les principes du droit de contrat pourraient tout aussi bien, ou mieux, servir aux parties du bail, que les principes du droit des biens, et propose des solutions à la problématigue éventuelle de la sécurité de l'occupation du locataire.

\section{TABLE OF CONTENTS}

I. INTRODUCTION . . . . . . . . . . . . . . . . . . . . . . 990

II. THE DEVElopMent OF THE PROPERTY/CONTRACT

HYBRID IN THE COURTS . . . . . . . . . . . . . . . . . 992

A. CANAdA: ABANDONMENT, SURRENDER, AND Mitigation . . . . . . . . . . . . . . . . . 992

B. CANADA: THE INDEPENDENCE OF COVENANTS

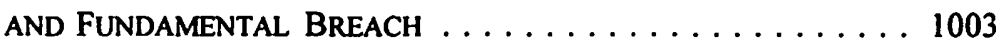

C. OTHER COMMON LAW JURISDICTIONS $\ldots \ldots \ldots \ldots \ldots \ldots .1008$

III. THE Merits of Contractualization $\ldots \ldots \ldots \ldots \ldots \ldots 1015$

A. INTRODUCTION . . . . . . . . . . . . . 1015

B. ARGUMENTS FOR CONTRACTUALIZATION $\ldots \ldots \ldots \ldots 1016$

IV. THE CONSEQUENCES OF COMPLETE

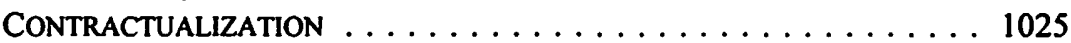

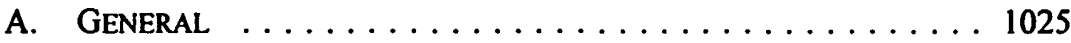

B. THE PROBlem OF THE TENANT'S

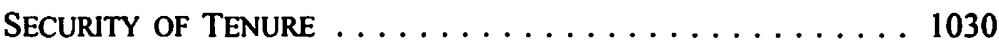

Jason Brock is a third-year student in the LL.B. program, Faculty of Law, University of Toronto. Jim Phillips is Professor of Law in the Faculty of Law and Centre of Criminology, University of Toronto. We thank the Wright Foundation for Legal Scholarship for financial support and Professor Bruce Ziff, University of Alberta, Faculty of Law, for helpful comments on a previous draft of this article. 
V. Conclusion $\ldots \ldots \ldots \ldots \ldots \ldots \ldots \ldots \ldots \ldots \ldots \ldots \ldots$

\section{INTRODUCTION}

Perhaps the most basic axiom of the common law of landlord and tenant is that it is property law, not contract law. That is, the common law has long treated the lease as first and foremost a conveyance of the land, as a grant of the right to exclusive possession for a certain, or potentially certain, period of time.' Although an agreement to lease is a contract, and although the landlord-tenant relationship is thus created by contract, once the tenant has gone into possession the relationship of landlord and tenant is no longer contractual. It is not regarded as an ongoing bargain for the use of land as opposed to some other good, but essentially as a "property" relationship. Landlords and tenants are governed by a regime which is conceptually modelled on the legal regime that governs persons with different interests in freehold land, not on that which generally orders the actions of contracting parties. ${ }^{2}$ While no longer applicable to residential tenancies, that regime remains very much in force for commercial leases.

This conceptualization of the lease as property, rather than as contract, has long historical roots. Its practical consequences for commercial leases are many. Landlords, for example, have a special remedial regime for collecting rent owed to them: distress. Also, the law has substantially resisted any suggestion that there be an implied warranty of fitness in a lease. ${ }^{3}$ Both landlord and tenant, moreover, may alienate their interest without fear of nullifying their original bargain through loss of privity. Finally, and as will be discussed much more fully below, the property paradigm means that contract doctrines such as mitigation and fundamental breach have not traditionally been applied to leases. ${ }^{4}$

While statutory reforms in all common law provinces since the 1960 s have, to a varying extent, transformed the residential lease into a regulated contract for accommodation, statutory changes to commercial lease law have actually served to reinforce the "property" nature of the lease. Limits on a landlord's ability to restrict the right to sub-let and assign, for example, can be seen as attempts to retain for the tenant a significant attribute of property ownership: the right to alienate. Similarly, statutory relief against forfeiture provisions may be regarded as recognizing the unique nature of

I See Cricklewood Property and Investment Trust v. Leighton's Investment Trust, [1945] A.C. 22] (H.L.) [hereinafter Cricklewood] at 233, per Lord Russell: "A lease is much more than a contract. It creates and vests in the lessee an estate or interest in the land."

2 As succinctly stated by Belzil D.C.J. in Crescent Motor Company and Pike v. North-West Tent and Awning Company (1970), 72 W.W.R. 694 at 699 (Alta. Dist. Ct.), "leases of real property and contracts for the sale of land, being both primarily grants of an estate in land, are governed by the same principles of law."

3 The common law does imply a covenant of fitness for use in furnished premises at the beginning of the term, although this is now largely irrelevant because fitness for use is a statutory requirement for residential tenancies and most commercial premises are, of course, unfurnished: see generally D. Stollery, "The Lease as a Contract" (1981) 19 Alta. L. Rev. 234 at 235-36.

- As well, the contractual doctrine of frustration has not traditionally been applied to leases: see J.T. Robertson, “Frustrated Leases: 'No to Never - But Rarely if Ever"” (1982) 60 Can. Bar Rev. 619. We discuss frustration more fully below in Section IV. 
land as a commodity, an acknowledgement designed to prevent the loss of vested rights in all but clear cases.

Despite this traditional conceptualization of the lease as property, the notion that commercial landlord-tenant law is essentially "property" law and fundamentally different from contract has been significantly, if haltingly, undermined in Canada in the last three decades. Judicial decisions in two areas in particular - abandonment and surrender, and the independence of covenants - have created something of a hybrid of classical lease and contract rules. This change began nearly 30 years ago with the decision of the Supreme Court of Canada in Highway Properties v. Kelly, Douglas and Co. Perhaps surprisingly, that decision has not prompted a major transition in the intervening years; the revolution it seemed to promise has not yet appeared.

Section II of this article is a largely descriptive analysis of this Canadian movement away from the traditional conception of the commercial lease as a conveyance, a movement we term "partial contractualization" of the commercial lease. ${ }^{6}$ It also briefly examines similar developments in other common law jurisdictions. It demonstrates that judicial innovation over the last three decades, in Canada in particular, has bequeathed us an essentially hybrid body of commercial lease law: a mixture of contract and property concepts and rules. This is a useful review in itself, an exercise in stock-taking, as well as a necessary prerequisite to the broader discussions which follow of the merits and consequences of what we term "complete contractualization."

In Section III we argue that the hybrid delineated in Section II is an unsatisfactory mixture, an inconsistent patchwork of approaches, and that the time has come to assimilate commercial landlord and tenant law within contract law. That conclusion leads us to Section IV, which examines a series of doctrines in landlord-tenant law which rest on the traditional conceptualization of the lease as a conveyance of an estate and which find no obvious corollaries in contract law: In each case, we suggest, little would be lost and much gained if the law were altered in the direction of complete contractualization. That is, we argue that the contract regime would serve perfectly well both parties to the traditional lease. The only exception to this would be the loss of a tenant's security of tenure for the agreed term, and in the final section of the article we suggest ways in which contract law could be used to respond to the tenant's legitimate desire to be secure in the bargained-for length of the term. contractualization" is the application of contract rules to the lease while the basic property conception of the lease is retained. It is therefore the production of a hybrid. It is this use of the term that is most prevalent in Section II of the article. By "complete contractualization" we mean the complete assimilation of the lease into a contract regime, and this use of the term comes to the fore in Sections III and IV. 


\section{The Development of the Property/Contract HYBRID IN THE COURTS}

\section{A. Canada: Abandonment, SurRender, ANd Mitigation}

We begin with this area of leasehold law because it permits an examination of the leading Supreme Court of Canada decision regarding the nature of the lease, the Highway Properties case. Highway Properties was the owner of a shopping centre and entered into a 15-year lease with Kelly, Douglas and Co., the tenant covenanting to use the premises as a supermarket. The tenant also covenanted to operate the supermarket continuously. The supermarket was unprofitable, largely because the shopping centre as a whole was a failure, and after a few years the supermarket was closed. Largely as a result of this, some three years after its opening, the shopping centre had become, in the words of Laskin J., a "ghost town."7 Kelly, Douglas announced that they were repudiating the lease, and Highway accepted that repudiation, took possession, split the supermarket into three units, and rented to other tenants. It sued for losses arising over the full term of the lease from the breach of the covenant to operate the grocery store on a continuous basis.

The landlord lost at trial and on appeal, on the basis of the peculiarities of the common law rules that govern the landlord-tenant relationship, which had been comprehensively reviewed and re-affirmed a decade or so earlier by the Ontario Court of Appeal in Goldhar v. Universal Sections and Mouldings. ${ }^{8}$ That is, when a tenant abandons the leased premises and seeks to repudiate a lease, the landlord has two principal courses of action. First, the landlord may refuse to accept the repudiation, and keep the lease alive. If this course is taken, the landlord has no right to enter the premises or to re-let them, and must then sue for lost rent and for damages flowing from breaches of any covenants, but only as each becomes due. That is, as Laskin J. put it, in a process of "instalment litigation." The landlord may keep the lease going indefinitely, there being no duty to mitigate losses.

The second possible course of action is that the landlord may expressly or impliedly accept the repudiation, thus bringing about the surrender of the lease. That is, surrender cannot be unilateral; it requires the landlord to accept an abandonment. On surrender, the right of possession reverts to the landlord. But once the lease is surrendered, all of the tenant's obligations to pay rent and to abide by any covenants in the lease are at an end. The tenant is liable for rent and for damages consequent on breach of covenant up to the point of surrender, but not thereafter. This "all or nothing" approach is somewhat tempered by a doctrine, discussed in more detail below, which permits the landlord to rent the premises to a sub-tenant on the tenant's behalf, but this is essentially a variation on the first course of action, keeping the leasehold relationship alive.

Highway Properties, supra note 5 at 713.

(1963), 36 D.L.R. (2d) 450 [hereinafter Goldhar]. For a review of the applicable rules and a comment on the Goldhar case, see A. Sternberg, "The Commercial Landlord's Duty to Mitigate Upon a Tenant's Abandonment of the Premises" (1985) 5 Advocates' Q. 385.

Highway Properties, supra note 5 at 721. 
The point that we draw from this review is that leasehold law is profoundly different from contract law in this kind of circumstance. Contract law provides that where one party repudiates a contract, the other party has the option of accepting that the relationship is at an end and suing for all damages that flow from the breach, subject to a duty to mitigate damages. In saying that the landlord may keep the lease alive when the tenant has repudiated, landlord-tenant law is also saying that there is no duty to mitigate. Similarly, in absolving the tenant from losses in the period after surrender, landlord-tenant law limits the "damages" that flow from the "breach" and thereby provides a substantial disincentive to the innocent party (the landlord) to do what seems sensible: to accept that the relationship is over and to move on in partnership with another tenant, although perhaps on less advantageous terms than those in the original lease.

In Highway Properties the Supreme Court of Canada for the first time made changes to these long-standing principles. Writing for a unanimous court, Laskin J. began by "acknowledging the continuity of common law principle that a lease of land for a term of years under which possession is taken creates an estate in the land." While ancillary covenants may in fact "overwhelm ... the leasehold estate," and while "commercial or business considerations [as expressed in those covenants]... represent the dominant features of the transaction," the estate aspect of the lease "has resisted displacement as the pivotal factor under the common law, at least as understood and administered in this country."10 Laskin $J$. then acknowledged that in other jurisdictions "[t]here has ... been some questioning of this persistent ascendancy of a concept that antedated the development of the law of contracts in English law and has been transformed in its social and economic aspects by urban living conditions and by commercial practice." "While limited statutory reform had made the lease more contractual in nature, "testifying to the paramount business considerations in a lease of land," such reform had "hitherto stopped short of full recognition of its remedial concomitants, as, for example, the principle of anticipatory breach and the principle governing relief upon repudiation."'2 Laskin J. saw no reason why anticipatory breach could not be applied to a lease, its "anticipatory feature" lying "in the fact that instalments of rent are payable for future periods." ${ }^{\prime 3}$ Repudiation therefore "raises the question whether an immediate remedy covering the loss of such rent and of other advantages extending over the unexpired term of the lease may be pursued notwithstanding that the estate in the land may have been terminated."'4

Laskin J. decided that such a remedy could be pursued; that is, a landlord could both bring about surrender of the lease by accepting a tenant's repudiation, and sue for future rent and all damages consequent on the breach of the lease and the covenants. This sea change in the common law's conceptualization of the lease stemmed, it would appear, from two principal considerations, one particular to abandonment by the tenant and one more general consideration, relating to the commercial milieu in which most leases are now made.

lbid. at 715 .

lbid.

lbid. at 715-16.

Ibid. at 716 .

$14 \quad$ Ibid. 
The particular consideration was that, although landlords formally had just the two options laid out above, they in fact had a third, a derivative of the option of keeping the lease alive. A line of cases, beginning with Walls v. Atcheson, ${ }^{15}$ established that the landlord could sub-let the premises on the tenant's account, as the tenant's agent, and in the short term enter into possession for the purpose of doing so. In effect, the landlord could receive the benefit of dealing with the premises and also keep the lease alive. To invoke this third option it was necessary for the landlord to give notice to the defaulting tenant of its intention to do so, and such notice served to negate what would otherwise have been the result of a landlord's entry: surrender of the lease by operation of law. Laskin J. saw this third option as the law's rather clumsy attempt to get around the traditional "all or nothing" approach, and criticized the fact that it was based on a highly unusual "unilateral assertion of unauthorized agency." ${ }^{16}$ In these circumstances a more direct route to the same result commended itself.

The second, more general, consideration which supported reform of the landlord's remedial armoury was the factual context in which commercial leases operated. It made no sense to continue to pretend that "a commercial lease ... is simply a conveyance and not also a contract."17 It was equally untenable "to persist in denying resort to the full armoury of remedies ordinarily available to redress repudiation of covenants, merely because the covenants may be associated with an estate in land."18

The result in Highway Properties was that the Supreme Court of Canada made it possible for landlords, on repudiation of the lease by the tenant, to "elect to terminate the lease but with notice to the defaulting tenant that damages will be claimed on the footing of a present recovery of damages for losing the benefit of the lease over its unexpired term."19 In short, the landlord could sue for damages flowing from breach, the principle on which damages in contract are awarded.

Before reviewing how courts have reacted to the case, it is necessary to stress that Highway Properties itself enunciated an apparently sweeping general principle - that commercial leases were contracts as well as conveyances - only to use it to ground a very modest reform. The court did not take away any of the landlord's existing options based on the notion of the lease as conveyance. It expressly stated that to the three existing options a landlord could pursue following a repudiation (accept surrender, keep the lease alive, keep the lease alive and let on the tenant's account) it was adding a fourth option. It did not remove the other three and require that the fourth option be taken in the vast majority of circumstances, which would have represented a true assimilation with contract law in this area. Thus the court signally failed to impose a duty to mitigate on Crozier v. Trevarton (1914), 32 O.L.R. 79 (C.A.); Green v. Tress (1927), 60 O.L.R. 151 (C.A.). Highway Properties, supra note 5 at 718.

17 Ibid. at 721. Although he did not say so, Laskin J. was likely thinking in particular of the continuous operation covenant, for such covenants are of major importance when a landlord is leasing to an "anchor" tenant such as a supermarket: see generally A. Kaufman, "Operating Clauses in Shopping Centre Leases" (1991) 18 Can. Bus. L.J. 245. 
the landlord, an issue which we discuss in more detail below. ${ }^{20}$ Subsequent decisions make it abundantly clear that, as a matter of practice, the three remedies traditionally available to landlords are still available. Landlords have been able to elect to keep the lease alive, ${ }^{21}$ and for all of Laskin J.'s fulminations against the "unilateral assertion of unauthorized agency," and despite the fact that there now seems little point in doing so, a landlord may still take the "third option."22

Perhaps most significantly, decisions subsequent to Highway Properties have established that even when a landlord elects to terminate the lease, it will not always be able to sue for prospective damages. Two points should be borne in mind here. First, under the old law a landlord who accepted surrender of the lease - and that could mean surrender by agreement or surrender by operation of law - lost the right to sue for anything other than accrued rent and damages to the time of termination. Second, in Highway Properties the court appears to state that for the landlord to terminate the lease and sue for damages over the unexpired term of the lease, it needed to give notice of its intention of doing so. Putting these two points together, we have a doctrine that states that if the landlord does something which converts an abandonment to a surrender, and fails to give notice that it intends to sue for prospective damages, it will be left only with the ability to sue for amounts owing to the date of surrender. Thus even in the one area in which Highway Properties clearly altered the old law (the addition of the prospective damages remedy), the Supreme Court of Canada created a regime unique to landlord and tenant law. Innocent parties in breaches of contract do not generally need to give notice that they intend to sue for damages.

Thus one commentator's claim that Highway Properties "rejected the traditional property approach in favour of a contractual analysis" is somewhat of an exaggeration: Sternberg, supra note 8 at 390. See, for example, E. Parker Enterprises v. Dud Hut Lid. (1979), 8 R.P.R. 322 (N.S.S.C.(T.D.)) [hereinafter E. Parker Enterprises]; 607190 Ontario v. First Consolidated Holdings Corp. (1992), 26 R.P.R. (2d.) 298 (Ont. Div. Ct.); Almad Investments v. Mister Leonard Holdings, [1996] 0.J. No. 870 (Gen. Div.), affd [1996] O.J. No. 4074 (C.A.), online: QL (OJRE) [hereinafter Almad Investments cited to O.J. No. 4074]. See also the discussion of mitigation, infra. See, inter alia, Commercial Credit Corp. v. Harry D. Shields Lid. (1980), 112 D.L.R. (3d) 153 (Ont. H.C.); B.G. Preeco 3 Lid. v. Universal Explorations (1987), 54 Alta. L.R. (2d) 65 at 74 (Q.B.) [hereinafter B.G. Preeco]; 859587 Ontario v. Starmark Property Management (1997), 34 O.R. (3d) 43 (Gen. Div.). These cases demonstrate that the agency option is not "obsolete," as claimed by Stemberg, supra note 8 at 393 . Note also that the continuing attachment to "property" rules is such that it has been held that if the landlord purports to re-let as agent for a term greater than the original lease, its actions will be construed as an acceptance of the surrender of the lease, on the grounds that it could not as agent of the tenant give a longer lease than the tenant had: see Pacific Centre v. Micro Base Development Corp. (1990), 43 B.C.L.R. (2d) 77 (S.C.). 
This notice requirement is a unique and somewhat perplexing addition to the law. ${ }^{23}$ It is likely, in fact, that Laskin J. did not intend to impose any special notice, merely intended that the repudiating tenant be given an opportunity to "make a go" of the lease. That is, the notice requirement represents nothing more than conformity with the contractual doctrine that the innocent party is required to let the contract-breaker know whether or not it intends to accept repudiation of the contract or whether it elects to insist on performance. ${ }^{24}$ It is instructive that when the Supreme Court of Canada applied the Highway Properties remedy to chattel leases, it did not, in a case where the lease was terminated by the lessor rather than repudiated by the lessee, insist on notice to the lessee. ${ }^{25}$ Whatever Laskin J. intended, however, subsequent courts have, at least formally, required special notice, ${ }^{26}$ although it may be that, in Ontario at least, the requirement has

Nothing in Laskin J.'s judgment explains why there should be special notice, a fact noted in one recent commentary on the notice requirement: see J. Lem, C. Blais \& H. Blaikie, Annotation, (1998), 20 R.P.R. (3d) 113 at 113-14. If indeed he intended to require it, the notion may have derived from the notice that a landlord previously had to give when invoking the "third course": that of re-letting on the tenant's account. But given that one principal purpose of allowing the landlord to terminate the lease and to sue for prospective damages was the court's dissatisfaction with the third option (particularly with the "unilateral assertion of unauthorized agency" that was contained in the notice), this explanation makes little sense.

On repudiation of contracts, see D.M. McRae, "Repudiation of Contracts in Canadian Law" (1978) 56 Can. Bar Rev. 233. Support for this idea comes from the judgment in Highway Properties itself. Laskin J. stated the notice requirement in one place, in the form of a restatement of the argument presented by counsel for Highway Properties. He summarized counsel's position as being that a "fourth option" for the landlord should be added, that the landlord "might elect to terminate the lease but with notice to the defaulting tenant that damages will be claimed on the footing of a present recovery of damages for losing the benefit of the lease over its unexpired term" (ibid. at 716). But in his conclusion, the notice requirement vanishes. He stated that "repudiation by the tenant gives the landlord at that time a choice between holding the tenant to the lease or terminating it, yet at the same time a right of action for damages then arises; and the election to insist on the lease or to refuse further performance ... goes simply to the measure and range of damages" (ibid. at 721). The latter passage, and particularly the use of the word "election," suggests that the court was concerned to ensure that the landlord inform the tenant of its election, but imposed no particular notice requirement. This argument is made in S.I. Bushnell, "Alternatives Available to a Landlord When a Tenant Wrongfully Abandons Rented Premises" (1975) 23 Chitty's L.J. 315. See also the suggestion that "[t]here is no particular reason for the landlord to give notice": A. Weinrib, "Property, Precedent and Policy" (1985) 35 U.T.L.J. 542 at 547. Militating against this argument, perhaps, is the fact that the affirmation option is unlikely in the circumstances of an abandonment, because the tenant has not committed a minor breach but a breach that destroys the whole purpose of the lease/contract. A further problem is that such notice goes well beyond the election issue, for, as one commentator has pointed out, "notice is simply one possible method by which the landlord can make its election to either affirm the lease or accept the tenant's repudiation": G. Sustrick, "Highway Properties - Look Both Ways Before Crossing" (1986) 24 Alta. L. Rev. 477 at 485 . For a discussion of "election" in the context of landlord-tenant law see P. Perell, "Landlords' Rights to End a Commercial Lease and Claim Damages" (1993) 2 Nat'l Real P. L.R. 211 at 220-22. Keneric Tractor Sales v. Langille (1987), 43 D.L.R. (4th) 171 (S.C.C.) [hereinafter Keneric Tractor]. See, for example, Daulat Investments v. Ceci's Home for Children (1991), 85 D.L.R. (4th) 248 (Ont. Gen. Div.) at 261, where a landlord was prevented from suing a tenant because it had accepted the surrender of the lease and "said or did nothing" at that time or at any point thereafter until it went to court. In Blue Chip Investments v. Hicks (1985), 54 Nfld. \& P.E.I.R. 260 at 263, the Court of Appeal for Newfoundland rejected a landlord's claim for prospective rent and damages because it failed to give any notice. Gushue J.A. stated that Highway Properties made it "clear" that "notice to the tenant is required," that "once the lease is at an end, the landlord must give timely notice to the tenant of any intentions he has to proceed against the tenant in damages." See also Forbes v. Wellsley 
been substantially eroded by the fact that the notice may be given in the statement of claim. ${ }^{27}$ In only one case has it been merely equated with election, ${ }^{28}$ there has been no explicit suggestion that it should be done away with altogether, ${ }^{29}$ and it is common for practising lawyers in the area to refer to this requirement as a "Highway Properties" or a "Kelly Douglas" notice.

Highway Properties both made a significant change to the particular legal rules governing landlords' remedies when a tenant abandons, and grounded that change in an apparent general reconceptualization of the legal nature of the lease. At the time it was seen as a significant milestone in Canadian leasehold law, ${ }^{31}$ and subsequent writers have referred to it as "ground-breaking," ${ }^{32}$ as a "great shift in analysis," 33 as having

Investments, [1997] B.C.J. No. 175 (S.C.), online: QL (BCJR).

The law on the timing of the notice is unclear. A line of cases in the 1970s and the early 1980s established not only that there must be notice, but also that the notice must be more or less contemporaneous with the notice that terminated the lease and brought about a surrender: see, inter alia, Fuda v. D'Angelo (1974), 2 O.R. (2d) 605 (H.C.); Blight Enterprises v. Great Eastern Furniture and Appliances (1979) Co. (1982), 39 Nfld. \& P.E.I.R. 327 (Nfld. S.C.(T.D.)); $R$. Millward Insurance Consultants v. Nationwide Advertising Service (1982), 48 A.R. 284 (Q.B.). The need for contemporaneity, and perhaps the need for notice at all, was done away with in Ontario in North Bay T.V. and Audio v. Nova Electronics (1984), 4 D.L.R. (4th) 88 (Ont. H.C.), affd (1984), 47 O.R. (2d) 588 (C.A.). In this case, where the tenant abandoned in July and notice claiming prospective damages was issued in August in a statement of claim, the Court of Appeal for Ontario at 588 briefly stated its agreement with the trial judge "that notice of intention to claim damages for prospective loss of rent need not be given contemporaneously with the termination of the tenancy." The court went on to say that "notice given by the commencement of proceedings was sufficient to found the claim for damages in this case." This latter phrase in the court's short endorsement leaves it unclear whether notice in a statement of claim was thought to be sufficient, or whether the crucial factor was the rapid issuing of the writ. If the ratio of the case is the former, it effectively obviates the need for special notice in Ontario; this is the view expressed in Weinrib, supra note 24 at 547. But it is also possible to see the Court as retaining the need for "timely," if not contemporaneous, notice. Only one Ontario case has held that notice in the statement of claim is always sufficient (Morrison Lamothe Inc. v. Bedok (1986), 29 D.L.R. (4th) 255 (Ont. H.C.) [hereinafter Morrison Lamothe]), and a number of cases, from Ontario and elsewhere, have held that the notice need be "timely" even if not contemporaneous with termination, and that the statement of claim does not necessarily meet the case: see the cases reviewed in Perell, supra note 24 at 233 , and see also Lem, Blais \& Blaikie, supra note 23. There is also recent authority from British Columbia that the requirement is actually for contemporaneous, not just timely, notice: see Marathon Realty Company v. Pogon Professional Services Corp. (1994), 36 R.P.R. (2d) 264 (B.C.S.C.). Calmonton Investments v. Tangye (1988), 87 A.R. 22 (C.A.).

However, some cases hold that no notice is required if the lease itself provides that the balance of rent owing or some other head of damages becomes due on termination: see Veysoglu v. O'Keefe and Goudie (1989), 81 Nfld. \& P.E.I.R. 317 (Nfld. S.C.(T.D.)); Morrison Lamothe, supra note 27; PamCor Investments v. Friends and Neighbours Family Restaurant (1987), 19 B.C.L.R. (2d) 324 (S.C.). But see contra, Langley Crossing Shopping Centre v. North-West Produce (1998), 20 R.P.R. (3d) 112 (B.C.S.C.), in which the court stated that separate notice was still necessary at the time of termination. Canada has now armed the modern combatant in landlord-and-tenant litigation with modern weapons." 
"revolutionized Canadian Law,"34 and as "demand[ing] a reconsideration of the conceptual framework" of landlord-tenant law. ${ }^{35}$ Yet it really represents not a reconceptualization of leasehold law, but a hybridization, ${ }^{36}$ importing a mix of contract rules into what is still a property-dominated paradigm. Its suggestion that the commercial lease is more properly conceived of as a contract than as an estate, while it is often cited, has not until very recently been used by the courts to rethink other important aspects of landlord-tenant law. ${ }^{37}$ The case has only been used once as a basis for further legal reform by the Supreme Court of Canada, and that was in the area of chattel leases. ${ }^{38}$ The failure to go further is exemplified by the way that the Court in Highway Properties as well as subsequent courts have dealt with the question of mitigation, and it is to that issue we now turn.

Before Highway Properties, the law on mitigation in landlord-tenant relationships was clear: it did not apply, being a principle of contract and not leasehold law. ${ }^{39}$ In Highway Properties, Laskin J. made only one mention of mitigation. Following his discussion of the landlord's option to keep the lease alive and to re-let the premises on the tenant's account, he stated briefly: "I know that under the present case law the landlord is not under a duty of mitigation, but mitigation is in fact involved where there is a re-letting on the tenant's account." ${ }^{10}$ This clearly does not impose a positive duty to mitigate. Moreover, it must be remembered that the option of keeping the lease alive was left

B. Bernstein, "Remedies for Breaches of Commercial Leases" in Law Society of Upper Canada, Bar Admission Materials 1986-1987: Real Estate and Landlord and Tenant (Toronto: Law Society of Upper Canada, 1986) at 701 .

Perell, supra note 24 at 212. For similar comments, see also A. Zaldin, "The Double Nature of a Lease - A Hybrid Document" in H. Haber, ed., Shopping Centre Leases (Toronto: Canada Law Book, 1976) 15; J.W. Lem, "The Landlord's Duty to Mitigate Upon a Tenant's Repudiation of a Commercial Lease: A Commentary on 607190 Ontario Inc. v. First Consolidated Holdings Corp." (1993), 30 R.P.R. (2d) 33.

Ziff calls it "a composite of contract and property principles": supra note 32 at 253 . For judicial references to the lease as a hybrid of property and contract, see, inter alia, Jerol Investments $\mathbf{v}$. Deaco Holdings (1983), 28 Sask. R. 137 (Q.B.) [hereinafter Jerol Investments]; Birkdale Realty v. MacLean (1984), 64 N.S.R. (2d) 409 (Co. Ct.).

There are cases in which courts refer to leases as contracts, sometimes citing Highway Properties. In Globe Convestra v. Vucetic (1990), 15 R.P.R. (2d) 220 at 243 (Ont. Gen. Div.) [hereinafter Globe Convestra], for example, Taliano J. read Laskin J.'s judgment as largely "displac[ing] the traditional property analysis with that of the more appropriate principles of contract law." To similar effect is the suggestion by Hallett J. that it is "sensible" to "treat a lease as a commercial contract": $E$. Parker Enterprises, supra note 21 at 336 . We discuss infra one other area affected by the reconceptualization of the lease: fundamental breach.

See Keneric Tractor, supra note 25, in which the issue was whether the lessor, who had terminated the contract because of the lessee's breach and repossessed and sold the goods, could sue only for rent owing and not for other damages. There was authority for the proposition that this situation should be treated exactly like landlord-tenant law - the lessor only being allowed to sue for past rent due, not for future rent, once the contract was terminated: Canadian Acceptance Corp. v. Regent Park Butcher Shop (1969), 3 D.L.R. (3d) 304 (Man. C.A.). In Keneric Tractor, Wilson J. said that Highway Properties had changed the law relating to damages for a breach of a lease of land, therefore there was no reason why ordinary contractual principles should not apply in a breach of a lease of chattels. 
available. The failure to impose a duty to mitigate, in order to balance the benefits given to a landlord who may now sue for the whole benefit of the lease, is strikingly inconsistent with the apparently general principle of treating the lease as contract and not as conveyance as enunciated in Highway Properties.

In no case since Highway Properties has the Supreme Court of Canada had the opportunity to say more about mitigation. Provincial courts have dealt with the issue, but largely inconclusively and, to some extent, inconsistently. For many years the leading case was Toronto Housing Co. v. Postal Promotions, ${ }^{41}$ which involved a 20 -year lease and a tenant who left the premises approximately one year into the term. The building stayed vacant for nine months, and the landlord then terminated the lease and let the premises to another tenant at a higher rent than the original tenant paid, so much so that the extra rent that would be received over the term of the new lease was considerably more than would have been paid under the original lease with Postal Promotions. The landlord claimed, inter alia, for rent arrears. Its argument, as summarized by Montgomery J. at trial, was that Highway Properties should be interpreted narrowly. It permitted a landlord to keep the original lease going, and the landlord had done so for a time. It also gave the landlord the right to accept the surrender and sue only for rent due to that point, which had later been done. And on that latter occasion, the landlord had not given notice of a claim for future losses, restricting its claim to rent due and unpaid while the lease subsisted. Thus no mitigation was involved.

Montgomery J. preferred the tenant's argument that the landlord had suffered no actual damages because the landlord had mitigated all of its damages with the new lease. But he did not rest this conclusion on Highway Properties; indeed he thought that the landlord had interpreted the case correctly. Instead, he cited a later decision of the Supreme Court of Canada, Windmill Place v. APECO of Canada, ${ }^{42}$ for the principle that "rentals received from a subsequent tenant were in mitigation of damages." 43 And on the facts the landlord's claim was indeed totally mitigated. The difficulty with the court's reasoning is that Windmill Place involved the breach of an agreement to lease, and was therefore decided on the basis of contract law. Agreements to lease have always been treated as executory contracts, and therefore there has never been any question that contract rules, including the duty to mitigate, apply.

On appeal by the landlord, the Ontario Court of Appeal took a slightly different view of the matter, a view that left the mitigation issue unclear. Lacourcière J.A. appears to have acknowledged the inappropriateness of using the Windmill Place case, but he did not go on to decide whether there should be a duty to mitigate once the estate had been granted. The issue "was not whether the landlord had an obligation to mitigate its damages but whether it had, in fact, mitigated them." 44 And on the facts mitigation had occurred. Lacourcière J.A. found that Highway Properties "specifically preserves for the parties to

(1981), 128 D.L.R. (3d) 51 (Ont. H.C.), aff' (1982), 140 D.L.R. (3d) 117 (C.A.) thereinafter Postal Promotions]. A useful discussion of the case appears in Bernstein, supra note 34 at 743-44.

42

43

4 
a commercial lease the '...full armoury of remedies ordinarily available to redress repudiation of covenants..." and that the case provided the "complete answer" to the problem before him, for "[i]t needs to be expanded only to the extent of giving the tenant the same access as was given to the landlord to the full range of contractual remedies and defences." That is, "when damages are calculated on the basis of breach of contract, the distinction between rent accrued and prospective rent, or damages for other breaches of covenant, are unimportant, the calculation being directed at placing the plaintiff in the same position as he would have been if all the covenants had been performed."4s

The appeal judgment in Postal Promotions therefore refuses to state that there is a duty to mitigate, but does hold that if mitigation occurs, if the landlord takes actions that reduce its damages, that mitigation will be counted. In coming to this conclusion, Lacourcière J.A. was in line with one part of Highway Properties. In discussing what the "damages" would be for a landlord "for losing the benefit of the lease over its unexpired term," Laskin J. stated that one measure of such damages would be "the unpaid future rent for the unexpired period of the lease less the actual rental value ... for that period." ${ }^{46}$ The Court of Appeal, rightly we think, took Laskin J.'s statement here to mean that if mitigation occurs (that is, if the landlord does re-rent the premises), it will be counted. Rent received from another goes only to what he termed "the measure and range of damages, ${ }^{277}$ but there is no duty to mitigate. Perhaps the most important holding in Postal Promotions is the rejection of the notion that a landlord can "mix and match" its remedies. It cannot for remedial purposes separate out periods of time - one when the lease was still alive and one when it had been surrendered - and sue for unpaid rent for the former without reference to what happened after surrender. ${ }^{48}$ But the court did not say that the landlord would not have been successful in obtaining a judgment for that unpaid rent had it sat idly by and done nothing to re-let the premises. ${ }^{49}$

On one further and relatively recent occasion the Ontario Court of Appeal has considered this issue, and apparently has decisively rejected the idea that there should be a duty to mitigate. In Almad Investments the court cited Highway Properties for the proposition that "the landlord has no duty to mitigate." issue, but we hesitate to label the decision thus. The judgment is little more than a onepage dismissal of an appeal of a summary judgment motion, in a case where the trial judge and the appeal court both felt that the landlord had in any event done all it could to mitigate. It evinces no real appreciation of the controversial nature of the problem before the court, and we can only assume that in a different context the reasoning would

Ibid. at 119.

Highway Properties, supra note 5 at 716.

Ibid. at 721.

A landlord was able to do this in Jerol Investments, supra note 36 at 141 . The tenant argued that a higher rental in the new post-surrender lease should be used to offset its liability for past rent due. Wright J. called this a "remarkable proposition" and stated that "[t]here is no duty on the plaintiff to confer the benefit of a higher rental on the defendant in order that the defendant may minimize the consequences of its unjustified breach of the head lease."

One commentator argues that Postal Promotions strongly implies a duty to mitigate: Sternberg, supra note 8 at 398 . Given that the court expressly refused to rule on the question, we respectfully disagree. Supra note 21 at 3. 
be fuller, even if the result was unchanged. Nonetheless, to the extent that we have authority on the point from the Court of Appeal, it is to the effect that there is no duty to mitigate.

A review of other cases demonstrates confusion and inconsistency on this point. There are many cases where the courts have, implicitly or explicitly, applied the Postal Promotions principle that if mitigation does occur it will be counted. ${ }^{51}$ But when courts have been asked to state whether the landlord must mitigate, they have provided inconsistent answers. Some cases have suggested that there is a duty to mitigate after the landlord has taken the fourth Highway Properties option, but not before. ${ }^{52}$ In a number of other cases there appear statements which either assume or explicitly hold that there is a duty to mitigate from the moment of repudiation by the tenant. Most notably, the British Columbia Supreme Court has come down very firmly in favour of a duty to mitigate. In Grouse Mechanical Co. v. Griffith it was baldly stated that "[o]nce the tenant breached his obligations or stated his intention to breach his obligations, the plaintiff had a duty to mitigate his loss." This duty could only be avoided in a situation in which the landlord had "substantial and legitimate interest in actual performance." ${ }^{53}$ Cowan J. took this latter notion from Asamera Oil Corp. v. Sea Oil and General Corp. ${ }^{54}$ the most recent word from the Supreme Court regarding the ability of an innocent party to a contract repudiation to insist on performance rather than to accept the repudiation. There was no discussion in this part of the judgment of any of the leading landlord and tenant cases on this topic.

These and other cases have led one commentator to suggest that "Canadian jurisprudence ... now appears to impose a duty on the part of the landlord to mitigate its

We do not wish to fill footnotes with examples, of which there are a great many. But see, inter alia, First Avenue Market Place v. Manthos (1994), 43 R.P.R. (2d) 282 (B.C.C.A.) [hereinafter First Avenue] at 291, in which the court stated that "the lessor is entitled to recover both past and prospective losses, but it must give credit for rent actually paid or reasonably expected to be paid over the term of the lease." Similarly, in Landcorp Ontario v. Hamdani Dry Cleaners (1990), 71 O.R. (2d) 673 at 676 (Div. Ct.) it was said to be unnecessary to consider whether there was a duty to mitigate, as in the case before it "there were steps taken to mitigate the damages."

See especially B.G. Preeco, supra note 22 at 75 . On abandonment by the tenant, the landlord elected to keep the lease alive and to try to sub-let as the tenant's agent. When it was not successful, the landlord sued for past and prospective rent. The court held, citing only Highway Properties, that there was no duty to mitigate during the period in which the lease was alive: "simply by waiting out the end of the term, ... the plaintiff would be entitled to judgment for the total rent owing under the lease, irrespective of the ... repudiation.... A duty to mitigate would never arise." Indeed, the period in which there was no duty to mitigate lasted up to the date of trial, which represented the moment of termination (by which the court presumably meant surrender) of the lease. At that point, "the ordinary principles of mitigation apply." See also the recent case of Falwyn Investors Group v. GPM Real Property (1998), 23 R.P.R. (3d) 1 (Ont. Gen. Div.) One commentator argues that most of the cases advocating the presence of a duty to mitigate have actually dealt with similar "fourth-option" situations: see Lem, supra note 35 at $38-40$. While this is certainly true of some, others, discussed infra, have suggested a more general duty to mitigate. 
losses in the event of repudiation by the tenant." ${ }^{\text {ss }}$ But that is, at best, an exaggeration, ${ }^{56}$ and the better view seems to be that there is no such duty. Two cases in particular have forcefully asserted this position. In an Ontario decision, 607190 Ontario v. First Consolidated Holdings Corp., the landlord insisted on keeping alive a lease which the tenant had repudiated. The landlord obtained summary judgment for rent arrears, but the tenant argued that such judgment should not have been granted because there was a triable issue on mitigation. Then $\mathrm{J}$. dismissed the appeal. He agreed that according to Highway Properties it remained "open to the landlord to avail himself of any of the mutually exclusive remedies" which the court had laid out. Of these, one was the option of keeping the lease alive. If the landlord chose this option, "no defence based on mitigation was available to the appellant." ${ }^{\text {"57 }}$

Likely the most significant recent decision in this area is that of the British Columbia Court of Appeal in Transco Mills v. Percan Enterprises. The Court held that when a landlord keeps the lease alive "and claims for rent due," there is "no basis on which ... [it] can be required to mitigate its loss." ${ }^{.58}$ The circumstances of this case were unusual. The tenant had been permitted to assign the lease on terms which clearly preserved the tenant's obligations to make all payments provided for in the lease. The assignee became bankrupt, and the trustee in bankruptcy disclaimed the lease. A large part of the judgment was taken up with whether or not the original tenants were bound by the lease following the disclaimer; the court found that they were. But these unusual circumstances made no difference to the issue before the court when it turned to the tenant's second argument, that of the landlord's duty to mitigate. While the court was technically correct in stating that the lease was alive following the trustee's disclaimer, the tenant repudiated at that point even though it did not abandon: there could be no abandonment where there was no possession. Thus the court, citing Highway Properties, held that the option of simply keeping the lease alive was still open to the landlord.

ss $\quad$ Sustrick, supra note 24 at 491.

36 Although see also the similarly broad statement of a duty to mitigate in Perell, supra note 24 at 232. Again, the cases where courts have held, or apparently have assumed, that there is a duty to mitigate, are too numerous to list here. Some are cited in Sustrick, ibid. at 490 . Notable examples include the Nova Scotia Court of Appeal's judgment in Windmill Place, supra note 42, a case involving an agreement to lease and not an executed lease, in which MacKeigan C.J. baldly stated that, following Highway Properties, a landlord whose tenant abandoned the premises was "entitled to damages on a contractual basis, subject to the doctrine of mitigation": (1976), 16 N.S.R. (2d) 565 at 571 . In Adanac Realty v. Humpty's Egg Place (1991), 78 Alta. L.R. (2d) 383 (Q.B.), Dea J., while he acknowledged that the case law was divided on the question, thought that the weight of authority and reason strongly supported the presence of such an obligation. This was a rare case, one in which the court went on to find that the landlord had not mitigated and reduced the damages accordingly. Another interesting case is Wild Dunes Holdings v. Hackett, [1998] B.C.J. No. 2336 (S.C.), online: QL (BCJR), where damages for breach of lease against an abandoning tenant were lowered because the landlord had not reasonably mitigated. See also Globe Convestra, supra note 37; Morrison Lamothe, supra note 27; Schreter v. Gasmac Inc. (1992), 7 O.R. (3d) 608 (Gen. Div.); Gander Shopping Centre v. Powell (1982), 39 Nfld. \& P.E.I.R. 313 (Nfld. Dist. Ct.); Wing Lee Holdings v. Starboard Dungaree [1995] B.C.J. No 805 (S.C.), rev'd [1996] B.C.J. No. 2144 (C.A.), online: QL (BCJR); L.A. Furniture v. 330061 Alberta, [1989] I W.W.R. 171 (Alta. Q.B.).

$58 \quad$ (1993), 100 D.L.R. (4th) 359 (B.C.C.A.) [hereinafter Transco Mills] at 370. 
The Court in Transco Mills was not persuaded by the Grouse Mechanical decision, which was distinguished because the landlord had chosen, following the tenant's stated intention to repudiate, to re-enter and to find another tenant. ${ }^{59}$ Nor was the Court persuaded that it should follow the advice of the province's Law Reform Commission, which had proposed a duty to mitigate in commercial tenancies: "If any such change in the law is to be made, it ought, in my view, to be made by the legislature, which is in a position to consider the full range of commercial interests at stake, rather than on the basis of the necessarily limited submissions of two parties to a lawsuit, and I would certainly not be prepared to take such a step in the present case."61 It is ironic that the British Columbia Court of Appeal should have taken this view, given the lead that the same court has taken in construing leases as commercial contracts for the purposes of the law of fundamental breach - a matter discussed in detail below. It is also curious that Taylor J.A.'s last comment on the subject of mitigation was that "[b]ecause the present claims appear to me clearly to be for rent, ... no duty to mitigate can arise."62 This appears to suggest that if the claim had been for damages flowing from breach of covenant, there might have been such a duty. Not only does this distinction fly in the face of the Highway Properties decision which saw prospective rent as one measure of damages, it also makes little sense to suggest that there is a duty to mitigate in one circumstance and not in another, for mitigation of covenant damages will invariably require the finding of another tenant.

While Highway Properties effected a partial reform of the law relating to landlords' remedies in the face of tenant abandonment, it appears to have effectively done nothing in the related area of mitigation. Over the past three decades courts have alternatively assumed that there is such a duty; have believed that there was not such a duty but that there should be; have refused to say whether they are enunciating such a new doctrine; and have contented themselves with a conclusion that it does not matter, providing that mitigation has actually taken place. This uncertainty is in itself something that ought to be remedied; combined with the fact that it does seem logical to give the landlord an obligation which ordinarily in the law corresponds to their new right, one cannot but conclude that a case like Transco Mills is wrongly decided.

\section{B. Canada: The Independence of Covenants and Fundamental BReach}

The second area in which we can discern elements of a major conceptual shift in commercial lease law is that of the independence of covenants. Covenants in leases are considered independent of the grant of the estate; a breach does not end the landlordtenant relationship. Leases may contain a host of terms in addition to that which grants exclusive possession: terms relating to such matters as the supply of services, responsibility for repairs, and assignment and sub-letting. But with a few statutory

Ibid. at 372.

Law Reform Commission of British Columbia, Report on the Commercial Tenancy Act (Vancouver: The Commission, 1989).

Transco Mills, supra note 58 at 372.

Ibid. at 373. 
exceptions, ${ }^{63}$ breach of covenant, no matter how serious, does not give a right in the innocent party to end the lease. As one text puts it, "[a]t common law nothing short of an eviction would suspend the obligation to pay rent." ${ }^{14}$ Thus contract doctrines like fundamental breach, and indeed frustration, have generally been held inapplicable to leases. Only if the lease is expressly made conditional on one of these terms is it possible to end the lease as a result of the breach, and then not on any theory of fundamental breach or repudiation, but on the same basis as that which ends conditional estates when the condition is breached. That is, the lease is like any other conditional estate. ${ }^{65}$

The point is nicely illustrated by Johnston v. Givens, ${ }^{66}$ even though the case dealt with a residential tenancy, an area now covered by statutory reforms in all provinces. Johnston leased an apartment to Givens. The lease contained a variety of covenants, including one that hot water would be provided and one that the landlord would provide "suitable means of heating" to a "reasonable temperature" from October to May ${ }^{67}$ The tenant discovered that the heating was inadequate, left at the end of November, and refused to pay rent. The apartment was not re-let until the following April, and then at a reduced rent. The landlord sued for rent and won on appeal. Robertson C.J. rested his finding on the general rule that "in default of any express provision to that effect the landlord's breaches of covenant do not entitle the tenant to declare the lease at an end. The landlord's covenant to heat the premises does not go to the whole consideration for the tenant's promise to pay rent." ${ }^{\text {"68 }}$ The tenant still had the estate, and "had no right to treat the lease as at an end, and to refuse to pay rent."

As with the "third option" of re-letting on the tenant's behalf when a tenant abandons, the common law has a partially fictitious device to get around the rigidity of the law when landlords fail substantially in their obligations under the lease. Tenants have at times been able to use the doctrine of constructive eviction as a kind of substitute for material breach, if the landlord's delinquency is sufficiently severe to merit more than a damages remedy for breach of covenant. ${ }^{70}$ Constructive eviction is "something of a grave and permanent character done by the landlord with the intention of depriving the tenant of the enjoyment

In Ontario, for example, legislation makes the covenant to pay rent and one restraining certain illegal uses into conditions: see Commercial Tenancies Act, R.S.O. 1990, c. L-7, ss. 18(1), 18(2) (the Act was formerly the Landlord and Tenant Act, with the name change being effected by S.O. 1997, c. 24, s. 213(5)). Other provincial legislation contains similar statutory conditions. See, for example, Landlord and Tenant Act, R.S.M. 1987, c. L-70, ss. 17(1), 17(2); Landlord and Tenant Act, R.S.N.B. 1973, c. L-1, ss. $8,9$. Ziff, supra note 32 at 273.

is See B. Laskin, Cases and Notes on Land Law (Toronto: University of Toronto Press, 1964) at 180: "Once, however, tenure was established, ...[a]part from express provision on the matter, the contract rule of dependency of promises was ignored. Thus, the tenant was not entitled to be excused from further performance or to terminate his lease unless there was a breach of condition by the landlord rather than a mere breach of covenant." [1941] 4 D.L.R. 634 (Ont. C.A.).

lbid. at 635.

Ibid. at 637.

Ibid. at 638.

For the "substitute" idea, see S.A. Siegal, "Is the Modern Lease a Contract or a Conveyance? - A Historical Inquiry" (1975) 52 J. Urban L. 649 at 679. 
of the demised premises." Many claims in this area have foundered on the need to show intention; this was the problem in Johnston v. Givens, for example, Robertson C.J. stating that "it is impossible to find that these were acts of a permanent characterdone by the landlord with the intention of depriving the tenant of the enjoyment of the demised premises." 72

It is rare to find in the cases explanations of the rule that lease covenants are independent. ${ }^{73}$ One circular justification sometimes cited is that the rule derives from the fact that the lease is primarily considered a conveyance. More convincingly, it is sometimes said that, as leases generally contain a variety of detailed provisions, the parties have the opportunity to provide for dependency if they so wish, by making the covenant a condition. The irony of this rationale, of course, is that it employs an essential attribute of contract law - that the parties' bargain should be honoured - to justify a refusal of the courts to apply an ancillary contract doctrine - that when one party significantly fails to honour the bargain, the other may elect to escape from it. Despite this, there has been no Supreme Court of Canada decision changing the law, even to the extent that Highway Properties altered the law on abandonment. Yet a series of cases, mostly from British Columbia, have shown provincial courts to be willing to import contractual principles into their analysis of certain lease covenants, sometimes in favour of tenants, sometimes to the benefit of landlords.

The leading case is Lehndorff Canadian Pension Properties v. Davis Management. ${ }^{74}$ Lehndorff owned an office building in Vancouver and Davis leased several floors in the building. Davis decided to move out because it obtained a better deal elsewhere, and assigned its leases to a third party, the owner of the office building to which Davis moved. The leases contained a standard covenant to the effect that the tenant would not assign or sublet without leave of the landlord, and that the landlord's consent to any assignment or sub-letting would not be unreasonably withheld. Lehndorff refused consent to the assignments, and Davis claimed the right to simply terminate the leases as a result. Lehndorff sued for the remainder of the rent due under the leases, but lost at trial, the trial judge holding that the refusal to consent to the assignments was unreasonable and that this amounted to constructive eviction.

In the Court of Appeal, Carrothers J.A., with whom Toy J.A. concurred, upheld the finding of the trial judge that the refusal to consent to the assignments was unreasonable. The issue remained whether this gave Davis the right to terminate, or merely to sue for damages. Carrothers J.A. rejected the idea that the landlord's action had amounted to constructive eviction and stated that he preferred not to construe the leases "as demises of real property" but "as commercial contracts." Highway Properties case. Then, from an examination of the context, he decided that a fundamental breach of contract had occurred when permission to sublet was refused. 
Therefore Davis "would not be limited to a remedy in damages and would not be liable to Lehndorff for further rent." ${ }^{166}$ Locke J.A. concurred, stating that by the logic of Highway Properties, "all contractual doctrines and remedies" applied to the leases, including the doctrine of fundamental breach. ${ }^{77} \mathrm{He}$ used the test from contract law to assess whether or not a fundamental breach had indeed occurred.

Lehndorff is clearly a very significant case, and has been recognized as such. ${ }^{78}$ It takes one of the underlying themes in Highway Properties - that there is no longer any reason to treat the commercial lease as a conveyance or as anything more than a contract for the use of land - and extends Highway Properties' use of contractual principles in one small area to a much broader field. And given that a number of other British Columbia cases (notably Wesbild Enterprises v. Pacific Stationers ${ }^{79}$ ) have taken the same line, it is reasonable to argue that the courts of that province have explicitly repudiated the doctrine of the independence of covenants. These courts now take for granted that they should be "[a]pplying principles of contract law to the interpretation" of leases. ${ }^{80}$ But again, it should be noted that, like Highway Properties, Lehndorff employs a hybrid of property and contract principles. The Court did not suggest that constructive eviction arguments should be abandoned for such cases, although they are likely to prove unnecessary. Any set of facts that could give rise to a successful constructive eviction claim would surely amount to a fundamental breach.

While there is much to recommend the approach of the British Columbia courts in this area, similar judicial reform has not taken general hold in Canadian common law provinces. Most courts appear to continue to adhere to the distinction between covenants and conditions when deciding if landlords or tenants have the right to treat the lease as ended. ${ }^{81}$ Indeed a recent review of landlord's remedies, concerned principally with Ontario, spends a good deal of time on the covenant/condition distinction, showing that it is still very much alive. ${ }^{82}$

Ibid. at 18.

Ibid. at 30 .

N. Bankes \& N. Rafferty, "A Tenant's Remedies for a Landlord's Breach: The Impact of Lehndorff Canadian Pension Properties Ltd. v. Davis Management Ltd." (1990) 24 U.B.C. L. Rev. 155, especially at $179-80$.

(1990), 14 R.P.R. (2d) 25 (B.C.C.A.). See also First Avenue, supra note 51, which assumes rather than discusses the applicability of contract rules. See also the reference to "breaches of a fundamental term of the lease" which could "justify repudiation" in 547495 Ontario v. Vanton Investments, [1994] B.C.J. No 2294 at para. 5 (S.C.), online: QL (BCJR), and to a landlord-tenant dispute being about "fundamental breach of a commercial contract" in Prince Business v. Vancouver Trade Mart (1994), 43 R.P.R. (2d) 228 at 229 (B.C.C.A.). See also 389079 B.C. v. Coast Hotels (1998), 19 R.P.R. (3d) 131 (B.C.S.C.); and, most recently, Shun Cheong Holdings B.C. v. Gold Ocean City Supermarket (1999), 31 R.P.R. (3d) 179 (B.C.S.C.).

Pin's Buildland Investment v. von Dehn (1991), 77 D.L.R. (4th) 566 at 572 (B.C.C.A.). See also $/ l$ Caminetto di Umberto Restaurant (1982) v. Watson (1997), 15 R.P.R. (3d) 243 (B.C.C.A.), in which the court held that a landlord had "repudiated" a lease.

See, inter alia, 461 King Street West v. 418 Wellington Parking (1994), 40 R.P.R. (2d) 220 (Ont. Gen. Div.); E. Parker Enterprises, supra note 21.

Bernstein, supra note 31 at 709-10, 746-49. The only Ontario case we could find which suggests that fundamental breach applies to commercial leases is Country Stop Donuts v. Great West Life Assurance (1996), 5 R.P.R. (3d) 187 (Ont. Gen. Div.). 
There are nonetheless a few signs that the independence of covenants is under attack elsewhere than in British Columbia. In Gateway Realty v. Arton Holdings and La Have Developments (No. 3), ${ }^{83}$ for example, the Nova Scotia Court of Appeal applied it to assist a landlord. Gateway leased space in its shopping centre to Zellers, which played the role of "anchor" store. Arton, a rival mall owner, lured Zellers to its shopping centre, and itself took an assignment of the lease held by Zellers in Gateway's mall, which at that time had 17 years remaining. At the time that it did this, Arton agreed to find a replacement tenant for the space vacated by Zellers. The Court of Appeal upheld the trial judge's finding that this agreement was in effect an amendment to the lease. When Arton failed to use its best efforts to get the replacement, it breached a "fundamental term" of the lease, according to the Court of Appeal, and this allowed the landlord to "rescind the contract of lease," to retake possession, and to rent to another store. Arton's failure "had the effect of literally destroying the viability of Gateway's Plaza Shopping Centre, contrary to any expectation in the original lease," and, as a result, "the deteriorating situation... became intolerable." ${ }^{84}$

The Court of Appeal judgment in Arton Holdings did not engage in an explicit discussion of the fact that it was importing a contractual principle (fundamental breach) into leasehold law. The short judgment reviewed and affirmed the most significant findings of fact by the trial judge and then simply assumed that contractual principles applied, even though the use of the contractual concept of "fundamental term" applied here is alien to traditional property law. At trial, however, Kelly J. cited on this issue both Highway Properties and Lehndorff and concluded that, as the "modern trend is to treat commercial leases as not simply a conveyance but also as a contract, ... there is no reason why the doctrine of fundamental breach should not apply to a contract of lease." ${ }^{.85}$

A number of other decisions also appear to demonstrate a willingness to apply contractual analysis to significant breaches of covenant. In Krenzel v. Interprovincial Security Patrol (Red Deer), ${ }^{86}$ the tenant argued that the failure of the landlord to repair and maintain the roof of the building constituted a "fundamental breach" of the lease entitling it to termination. In a curiously inconsistent judgment, the Court first found that although there was a breach of covenant in this respect, the tenant was not entitled to terminate the lease as a result. Among the authorities cited for this was Johnston v. Givens. However, the court went on to cite Highway Properties to the effect that "the remedies ordinarily available to redress repudiation of covenants may be resorted to even where these covenants are associated with an estate in land." ${ }^{87}$ It then appeared to suggest that this meant that it was possible to argue for fundamental breach, even if the facts of the case before it did not amount to this. Despite its inconsistencies, the case represents an interesting extension of Highway Properties - from a landlord's ability to sue on covenants despite the loss of the estate, to a tenant's ability to use breach of (1991), 106 N.S.R. (2d) 180 (S.C.(T.D.)), affd (1992), 112 N.S.R. (2d) 180 (C.A.) [hereinafter Arton Holdings].

lbid. at 183 (C.A.).

Supra note 83 at 211 (S.C. (T.D.)).

(1982), 38 A.R. 153 (Q.B.).

lbid. at 172. 
covenant to argue a fundamental breach of the lease itself. This same approach of considering the possibility of a "fundamental breach of a lease" is also manifested in other cases. $^{88}$

This review of the fundamental breach cases offers a similar patchwork of inconsistency as noted in our first section. The inconsistency differs, in that reform seems more substantial in at least one jurisdiction rather than being partial in content across the country, but it is inconsistency nonetheless. Here too we may characterize Canadian commercial lease law as a hybrid of property and contract. Such inconsistency is not merely the result of Canadian circumstances. In the next section we demonstrate that hybridization is not unique to Canada. That is, to the extent that there are inconsistencies, they are shared by other jurisdictions with common law roots. This suggests to us that the traditional conception of the lease is ill-suited to commercial reality, an argument we later develop in advocating complete contractualization.

\section{Other COMmon LaW JURISDictions}

It is not simply Canadian jurisprudence which has produced this hybrid model. We believe that hybridization has resulted from the changing conditions of modern economies in general. That is, in broadly similar economies and contexts, the traditional approach to the commercial lease has also been undermined in similar ways, a uniformity of trends that cannot be a coincidence. In general, although there is a discernible movement toward the application of contractual principles in each of the jurisdictions discussed here - the United Kingdom, Australia, and the United States - the commercial lease has also retained a substantial number of property-based concepts. What has emerged in other jurisdictions, therefore, is, as in Canada, a hybrid of property and contract.

Courts in the United Kingdom have in recent years begun the task of making some contract doctrines applicable to commercial leases. The leading case is National Carriers v. Panalpina (Northern), ${ }^{89}$ in which the House of Lords held that the doctrine of frustration is applicable to leases. In doing so, they overturned a series of prior decisions which had held that neither this particular contract doctrine, nor contract law generally, can apply. ${ }^{90}$ In coming to this conclusion, some of the law lords referred with approval

See, inter alia, Pensionfund Realty v. MacCoshams Storage and Distribution Centres (Winnipeg) (1994), 38 R.P.R. (2d) 272 (Man. Q.B.); B.G. Preeco, supra note 22. In Dentrix Inc. v. Prudential Assurance Co. (1999), 26 R.P.R. (3d) 314 (Man. Q.B.), the court dismissed the claim for a fundamental breach not because it was not possible to argue this on breach of covenant, but because this had not occurred on the facts of the case. Indeed, it distinguished Arton Holdings on that basis. Although not quite on point, see also Homer v. Toronto Dominion Bank (1990), 83 Sask. R. 300 at 302, in which the Court of Appeal for Saskatchewan, in a lease case, criticized the trial judge for "overlook[ing] entirely the applicable principles of contract law."

[1981] A.C. 675 [hereinafter National Carriers]. For an extensive commentary, see Robertson, supra note 4.

Cricklewood, supra note 1 , is generally thought to stand for the proposition that frustration does not apply to leases, even though two judges said that it could, two said that it could not, and a fifth expressed no opinion on the matter. As a result, the old rule that frustration was inapplicable still stood. Total Oil Great Britain v. Thompson Garages (Biggin Hill), [1972] 1 Q.B. 318 (C.A.) cited Cricklewood as authority for the proposition that frustration does not apply to leases, and went further 
to Highway Properties. Lord Wilberforce described Laskin J.'s judgment as "instructive," quoting in particular the suggestion that it was "untenable to persist in denying resort to the full armoury of remedies ordinarily available to redress repudiation of covenants, merely because the covenants may be associated with an estate in land."91 Lord Roskill also cited the passage in support of his opinion, ${ }^{92}$ while Lord Simon referred to Laskin J.'s judgment as "important and relevant for its general reasoning."

National Carriers did more than hold that the doctrine of frustration applies to leases in English law. It also indicated that contractual doctrines will not be regarded, in principle, as inapplicable to leases. ${ }^{94}$ This has now been used to hold that repudiation can apply to leases. In Hussein v. Mehlman, Assistant Recorder Sedley (as he then was) held that a tenant could terminate a lease if the landlord acted in a manner which constituted a repudiatory breach. Indeed he thought it "axiomatic" that a lease "could be terminated by the innocent party without notice if the other party failed to fulfil a fundamental term of the contract." $\mathrm{He}$ included failure to pay rent, if it went to the root of the contract, as a repudiation by the tenant. Sedley purported to rely on some nineteenth-century authorities for his conclusions, but he was surely influenced by the general reasoning in Highway Properties and National Carriers. The case also likely has a wider significance than its contribution to the law on repudiatory breach. Prior to Hussein, it could be said with confidence that a landlord who terminated a lease could not sue the tenant prospectively for rent for the unexpired remainder of the term. After Hussein, however, prospective rent may be available as part of a claim for damages for breach, just as it is in Canada. ${ }^{96}$

These cases suggest that English law has become increasingly willing to view the lease as, at least in part, a contract for the use of land; certainly the courts no longer feel bound by the idea that classification as a conveyance entirely prevents the lease being treated as

to state that in general no contractual doctrines apply to leases, including the doctrine at issue in that case, that of repudiatory breach. Prior to the definitive statements of National Carriers, the idea that leases should be treated differently from other contracts had been weakened in United Scientific Holdings v. Burnley Borough Council, [1978] A.C. 904 (H.L.). In particular, in a passage reflecting contractual ideas, Lord Diplock noted, at 935: “[T]he mediaeval concept of rent as a service rendered by the tenant to the landlord has been displaced by the modem concept of a payment which a tenant is bound by his contract to pay to the landlord for the use of his land."

National Carriers, supra note 89 at 696.

lbid. at 716.

Ibid. at 703.

See also Hammersmith and Fulham London Borough Council v. Monk, [1992] 1 All E.R. I (H.L.), which adjudicated whether a joint tenancy was severed by one tenant only serving a notice to quit. The House of Lords said that it was, and in the process Lord Bridge stated, at 3: "As a matter of principle I see no reason why this question should receive any different answer in the context of the contractual relationship of landlord and tenant than that which it would receive in any other contractual context."

[1992] 2 E.G.L.R. 87 (Co. Ct.) [hereinafter Hussein] at 89-90. For discussions of this case, see C. Harpum, "Leases as Contracts" (1993) 52 Cambridge L.J. 212; M. Pawlowski, "Acceptance of Repudiatory Breach in Leases" (1995) 59 Conv. 379; S. Bright, "Repudfating a Lease - Contract Rules" (1993) 57 Conv. 71.

See Harpum, ibid. at 214. 
an ordinary contract. ${ }^{97}$ National Carriers is the English equivalent of Highway Properties, and the lease in English law is now generally on the same footing as it is in Canada: a hybrid of contract and property. Indeed, the House of Lords has recently gone so far as to extend this hybrid so that one can grant a "lease" without an estate. In Bruton v. London \& Quadrant Housing Trust, ${ }^{98}$ the trust had been given a licence to occupy properties by their owner, the local council, so that they could be used pending redevelopment. In turn, the trust gave Bruton the right to occupy a flat on a weekly licence. The development never took place, plans for it were abandoned, and by the time the matter was litigated Bruton had been living there for ten years. The House of Lords held that he had a "lease," based on his exclusive possession, despite the fact that the trust did not itself have an estate. This "lease," however, was not good against the whole world; it was therefore, in the words of one commentator, a "contractual [lease] conferring exclusive possession and giving rights against all who interfere with possession other than those who can show a better right to possession." 99

The history of the relationship between property and contract in Australian lease law is a convoluted one. As long ago as 1906 the High Court of Australia held that upon abandonment by the tenant of a commercial lease, the landlord was entitled to claim damages for the unexpired term. ${ }^{100}$ That is, it came to the same conclusion as the Supreme Court of Canada would some 65 years later. Indeed, Buchanan was cited by Laskin J. in his Highway Properties judgment. Barton J.'s judgment in the case strikes a decidedly contemporary note. When the tenant abandoned, he stated, "[t]here was at that time a renunciation which, at the plaintiff's option, amounted to a breach of the covenants." As a result, "[t] $]$ he plaintiff was then entitled to claim in an immediate action, prospectively, such damages as would be caused by a breach ... subject to any circumstances which might operate in mitigation of damages."

However, despite the fact that the court reiterated its position in another case shortly afterward, ${ }^{102}$ both the particular rule for which Buchanan stood - prospective damages on abandonment - and the general principle underlying it - that a lease should be treated, at least in some respects, as a contract - fell into abeyance. In subsequent abandonment cases Buchanan was restricted to its facts. ${ }^{103}$ More generally, it was ignored altogether. For example, when the High Court held that the doctrine of frustration did not apply to leases, it did not mention Buchanan. ${ }^{104}$ Even in the landmark case of

According to Bright, supra note 95 at 71,77 , the contractualization of leases is "a process that has been gathering pace in this country for the last 20 years," and that process means that in time most leases "will be assimilated with contracts." For a contrary view, see W. Barr, "Repudiation of Leases - A Fool's Paradise" in P. Jackson \& D. Wilde, eds., Contemporary Property Law (Aldershot: Ashgate/Dartmouth, 1999) at 317.

[1999] 3 W.L.R. 150 (H.L.). See generally P. Routley, "Tenancies and Estoppel - After Bruton v. London \& Quadrant Housing Trust" (2000) 63 Mod. L. Rev. 424.

S. Bright, "Leases, Exclusive Possession, and Estates" (2000) 116 L.Q. Rev. 7 at 9.

Buchanan v. Byrnes, [1906] 3 C.L.R. 704 [hereinafter Buchanan].

lbid. at 719.

Lamson Store Service v. Russell Wilkins \& Sons, [1906] 4 C.L.R. 672.

See the cases discussed in J. Effron, "The Contractualisation of the Law of Leasehold: Pitfalls and Opportunities" (1988) 14 Monash U.L. Rev. 83 at 85.

Firth v. Halloran (1926), 38 C.L.R. 261. 
Ripka Pty v. Maggiore Bakeries, ${ }^{105}$ one of the first Australian cases since Buchanan to apply contract doctrines to a lease both as a matter of principle and of fact, ${ }^{106}$ Buchanan itself was not mentioned. Instead, the holding that "the principle that a contract may be terminated by the acceptance of a repudiation" applies to commercial leases was supported by the authority of Highway Properties. Gray J. wrote, "the Highway Properties Case stands as the foremost direct authority relevant to the present point," and he concluded from it that "the doctrine of repudiation has general application to leases." 107

When the High Court next considered the question of applying contract doctrines to commercial leases in Progressive Mailing House Pty v. Tabali Pty, ${ }^{108}$ it returned to the decision in Buchanan. Citing that case as well as National Carriers and Highway Properties, Mason J. noted that "the balance of authority here as well as overseas... support[s] the proposition that the ordinary principles of contract law, including that of termination for repudiation or fundamental breach, apply to leases." 109 Mason J. was clear that, as a consequence, the common law "right to determine for repudiation or fundamental breach" 110 presumptively applied. Brennan J. was somewhat more cautious, arguing that while "ordinary contractual principles do apply to a lease," the "character of a lease as a demise distinguishes the consequences of their application from their application to a contract that is not also a demise." "II In other words, the lessor would be unable to determine the lease on the basis of anticipatory breach except where the lease was also liable to forfeiture. "It would be a curious law," Brennan J. explained, "which permitted a lessee in breach of covenant to seek relief against forfeiture while denying the prospect of relief to a lessee who had committed an anticipatory breach."1/2 Contractualization, according to Brennan J., must not obscure property-based relief. The court was clearly making an effort in Progressive Mailing to retain the dual character of

[1984] V.R. 629 (S.C.) [hereinafter Ripka].

There had been previous cases which hinted at doing so, or discussed it in the abstract, but contract law was not applied to come to a result. See, e.g., Leitz Leeholme Stud Pty v. Robinson, [1977] 2 N.S.W.L.R. 544 (C.A.) (favouring the application of repudiation to leases); Hughes v. N.L.S. Pty, [1966] W.A.R. 100 (S.C.) at 102, aff'd on different grounds (1966), 120 C.L.R. 583 (C.A.): "Unti] surrender, [the lessor] can sue for rent as such; after surrender, he is limited to damages for loss of rent flowing from the lessee's breach of contract." See also Shevill v. Builders Licensing Board (1982), 42 A.L.R. 305 at 308, in which the High Court assumed without deciding that the doctrine of repudiation applied. The Court held that the conduct of the lessee did not amount to a repudiation, but Gibbs C.J. was careful to limit the holding of the case: "[The] argument proceeded on the basis that the general principles of the law of contract, so far as they are relevant to the questions that arise in this case, are equally applicable to leases.... I need not enter upon this controversy. I am content to assume that the ordinary principles of contract law are applicable." For these cases and for a general discussion of the history, see Effron, supra note 103 at 87.

Ripka, supra note 105 at $630,632,634$.

[1985] 157 C.L.R. 17 [hereinafter Progressive Mailing]. For commentary, see C. Chew, "Leases Repudiated: The Application of the Contractual Doctrine of Repudiation to Real Property Leases" (1990) 20 U.W.A. L. Rev. 86.

Progressive Mailing, ibid. at 29.

Ibid. at 30.

Ibid. at $40-41$.

lbid. at 43. 
the lease as both contract and conveyance. ${ }^{113}$ In particular, Brennan J. was attempting to preserve some basis for relief against forfeiture by maintaining the property-based requirement of liability for forfeiture as a basis for termination. Even Mason J., in his application of contractual doctrines, affirmed that a lease vests an estate or an interest in land in the lessee.

A number of cases have followed Progressive Mailing. In Wood Factory Pty v. Kiritos Pty, ${ }^{114}$ for example, the New South Wales Court of Appeal awarded to the landlord the difference between the original rent and the new rent for the remaining term of the original lease (plus rent in arrears) after the tenant abandoned. The abandonment, with rent in arrears, was held to constitute a fundamental breach. In effect, the lessor was awarded expectation losses on the contract, set-off against the value of the mitigation. Here, and elsewhere, the courts have, as in Canada, held that mitigation will be counted if it occurs, and on one occasion have arguably made it into a duty. ${ }^{115}$

The invocation of fundamental breach has raised the issue of the status of the statutory requirements for forfeiture. In Nai Pty v. Hassoun Nominees Pty, ${ }^{116}$ the Supreme Court of South Australia found that a landlord need not comply with applicable statutory requirements for re-entry where a tenant had repudiated the lease, except where the landlord was re-entering under a stipulation of the lease. This ruling echoes Mason J.'s holding in Progressive Mailing that the common law right to determine for fundamental breach applies presumptively, unless the lease itself stipulates otherwise. In Marshall v. Snowy River Shire Council, ${ }^{117}$ the New South Wales Court of Appeal decided, similarly, that upon fundamental breach by the tenant, the landlord had both a contractual right to terminate by re-entry and a common law right to terminate for breach. In the former case, statutory requirements would apply, while in the latter case they would not.

In Australia, therefore, although the commercial lease retains its character as a conveyance, it has been contractualized to a substantial extent. Frustration, fundamental breach, repudiation, and the ability to terminate and sue for prospective rent are all part of the law. The absence of a clear duty to mitigate, the continued insistence that the lease is both a contract and a conveyance, and a concern that the doctrine of repudiation not "be used to evade" statutes which would otherwise apply, ${ }^{118}$ all show that full contractualization has not taken place. Therefore the Australian law, like the Canadian, is a hybrid of property and contract. But it is, it would appear, a hybrid with more emphasis on the contractual elements than is yet the case in Canada. ${ }^{119}$

See N. Shaw, "Contractualisation and the Lease-Licence Distinction" (1996) 18 Adel. L. Rev. 213 at 237.

[1985] 2 N.S.W.L.R. 105.

Vickers \& Vickers v. Stichtenoth Property Investments Pty (1989), 52 S.A.S.R. 90.

116 [1985] A.N.Z. Conv. R. 349, as cited in Effron, supra note 103 at 90-91. See also generally Effron, ibid. at 91; P. Butt, "The Contractualisation of Leases: A Further Step?" (1996) 70 A.L.J. 97 at 100. [1994] NSW LEXIS 13646, online: LEXIS.

Effron, supra note 103 at 91 . See also Buth, supra note 116 at 100.

Ziff makes this point, asserting that in general both Australia and New Zealand have taken the contractualization notion further than has Canada: supra note 32 at 268. 
We conclude this review of other jurisdictions with a very brief examination of the United States. It is brief because the landlord-tenant relationship is a state matter, ${ }^{120}$ and we cannot hope to review all states, an enterprise which would in any event be superfluous to current requirements. Three general points can nonetheless be made. First, through the nineteenth and early twentieth centuries American law was very similar to English common law: the lease created essentially a property, not a contractual, relationship. ${ }^{121}$ Second, a few states have retained the largely property-based conception of that law. ${ }^{122}$ Third, the majority of states' courts have, to a greater or lesser degree, imported contractual principles into commercial lease law. A leading real property text argues that "at present, the law of leases reflects its historical development: it remains a blend of property concepts and contractual doctrines." 123

An example of this hybrid approach may be found in the law relating to the question at issue in Highway Properties: landlords' remedies on abandonment. Most states permit landlords to sue for prospective rent. The Supreme Court of Colorado, for example, has reasoned that "it is necessary to recognize the dual nature of the lease as contract and conveyance... [in order] to achieve a just result."124 This was necessary because it allowed for an expectation remedy for the landlord in the face of the traditional rule. Due to the dual nature of the lease, "acceptance of surrender acts to terminate the privity of estate between the parties but the privity of contract between them is held to be unaffected." Accordingly, "while a landlord can no longer maintain an action for rent ... he can maintain an action for contract damages." ${ }^{25}$ The court retained a property-based

In 1971, the United States Supreme Court held that the nature of the landlord-tenant relationship is a matter for state legislatures and courts: see Lindsey v. Normet, 405 U.S. 56 (1971) at 74.

The Supreme Court summarized the law in 1886 as follows: "The common law regards ... a lease as the grant of an estate for years, which the lessee takes a title in, and is bound to pay the stipulated rent for, notwithstanding any injury by flood, fire, or external violence, at least unless the injury is such a destruction of the land as to amount to an eviction" (Viterbo v. Friedlander, 120 U.S. 707, (1886) at 712). The only exception (sometimes called the "American exception" but effectively applying frustration) was in cases involving the destruction of leased premises, in which circumstances the tenant would be excused from the rent obligation. The exception was founded on the idea that in such situations " $i t$ is not the intention of the lease to grant any interest in the land, save for the single purpose of the enjoyment of the apartment demised, and when that enjoyment becomes impossible, by reason of the destruction of the building, there remains nothing upon which the demise can operate": Womack v. McQuarry, 28 Ind. 103 (1867) at 104. Although couched in the language of estates, the exception recognized that the intended purpose of the leases in question was not the conveyance of an interest in land, but the use of a particular space for a term. Exception cases, therefore, effectively viewed the lease "as a contract for use and occupation rather than a conveyance": A.L. Corbin, Corbin on Contracts, vol. 6 (St. Paul: West Publishing, 1962) at 470. For example, although lower courts in New York have been willing to apply contractual principles to the lease (see Lefrak v. Lambert, 390 N.Y.S.2d 959 (Civ. Ct. 1976)), the New York Court of Appeals recently upheld a purely property-based approach: see Holy Properties v. Kenneth Cole Productions, 661 N.E.2d 694 (N.Y. 1995).

R. Powell \& P.J. Rohan, Powell on Real Property, vol. 2 (New York: Matthew Bender, 1995) at 187. See also M.R. Friedman, Friedman on Leases, vol. 1, 4th ed. (New York: Practising Law Institute, 1997) at 10, n. 29, where the author notes a "tendency to depart from the estate concept in commercial leases." See also generally E. Chase \& E.H. Taylor, "Landlord and Tenant: A Study in Property and Contract" (1985) 30 Vill. L. Rev. 571.

Schneiker v. Gordon, 732 P.2d 603 (Colo. 1987) [hereinafter Schneiker] at 610.

Ibid. at 608. 
conception of the lease, even while the dual character of the lease was used to justify a contractual remedy. The court in Schneiker also imposed a duty to mitigate, but this is by no means the universal view; indeed there is "a significant split of authority" on whether there should be such a duty. ${ }^{126}$

Three further points are worth noting. First, some courts have taken contractualization into the areas of the independence of covenants and fundamental breach, ${ }^{127}$ although as in Canada this has not been a substantial development. Second, a number of state courts have refused to imply warranties of suitability into commercial leases, using contract principles as the justification. For example, in E.P. Hinkel \& Co. v. Manhattan Co., an implied warranty of suitability was refused on the basis that "in a commercial lease negotiated between parties of equal bargaining power ... there is no reason to modify the common law rule."128 This and other cases demonstrate a reluctance to part with traditional property-based rules, even as the courts emphasize the contractual nature of the relationship. ${ }^{129}$

Third, some recent cases have gone beyond the merely supplemental usage of contractual ideas and have questioned the very retention of a property-based approach. In Cain Partnership v. Pioneer Investment Services, the Supreme Court of Tennessee described the "present status" of the lease as one with rights and obligations based on "two independent grounds," 130 property and contract. The Court then noted "the failure of these traditional common law rules of property law to accommodate present business conditions." ${ }^{131}$ In an innovative move, it applied the contract doctrine of mutuality directly. In Reid v. Mutual of Omaha Insurance Co., ${ }^{132}$ the Supreme Court of Utah was equally explicit. Commenting on Schneiker, the majority suggested that the court there had not adequately considered whether abandonment by the tenant would terminate both the property and the contractual relations. "Our view," wrote the majority, "is that the property and/or contract relationship between the parties can be effectively terminated by words or conduct that sufficiently demonstrates an intent to do so." 133 The court then eschewed the idea that a lease conveys an estate: "Today, leases are generally viewed as commercial transactions in which the landlord retains the estate but permits its use by another." 134

126 E. Smith, "Extending the Contractual Duty to Mitigate Damages to Landlords When a Tenant Abandons the Lease" (1990) 42 Baylor L. Rev. 553 at 553.

See the early case of University Club of Chicago v. Deakin, 106 N.E. 790 (S.C. III. 1914) at 791, where the lease was described as a "bilateral contract," and breach of an "essential provision" by the landlord was held to "warrant [the tenant] in rescinding the contract and surrendering possession." 506 F.2d 201 (D.C. Cir. 1974) at 206.

See also Service Oil Co. v. White, 542 P.2d 652 (S.C. Kan. 1975) at 659, in which it was held that because the lessee of commercial property "does not generally occupy an inferior bargaining position," it is appropriate to "decline to engraft an implied warranty of suitability" upon parties to a commercial lease. 
Courts in the United States have been increasingly willing to apply contract-based ideas to commercial leases. The cases suggest that the law has been moving away from an exclusively property-based approach, toward a more flexible approach which would allow for the application of contractual doctrines to the lease. That application, however, has been tempered by the preservation of property-based ideas. Ultimately, despite a few recent innovative suggestions, the commercial lease in the United States is a hybrid of contract and property ideas. Or, as one court has concluded, "the modern lease is both a conveyance and a contract." 135

\section{The Merits of Contractualization}

\section{A. INTRODUCTION}

In the preceding section we demonstrated that aspects of commercial lease law, in Canada and elsewhere, have tended, as one commentator has put it, to oscillate "between the magnetic poles of contract and property." 136 .In this section and in the one that follows, we argue that the Canadian trend of partial contractualization delineated in Section II should be accelerated, to the point that the law becomes fully assimilated with contract law. Our argument is developed in two principal ways. In Section IV we will review a series of areas of the current landlord-tenant regime which would be affected by a move to complete contractualization. We will argue that those effects are to be welcomed; but in one area, security of tenure for tenants, we see a problem, and suggest ways to deal with that problem.

First, however, we review the arguments in favour of full contractualization. The principal one, contained in the first subsection, is that the character of the modern commercial lease renders it much more amenable to categorization as a contract than as a conveyance. We first spend some time on the history of the lease, in order to demonstrate that there is nothing in that history, or in the nature of leases, that requires that they be analyzed as estates. They began as contracts, and were only conceptualized as property because of certain contingent historical circumstances. Thus nothing now prevents a return to contract. We then compare the nature of the modern lease with the kinds of leases that gave rise to the traditional conceptualization, and argue that because the modern lease is in reality a contract for much more than land, full contractualization is warranted.

We see the arguments advanced in this first subsection as the most compelling ones for contractualization. But they are not the only ones, and in subsequent subsections we examine others. We argue, in subsection 2, that contractualization will serve the goal of permitting the parties to leases the freedom to bargain for their own regime. In subsections 3 and 4 we briefly review other reasons for contractualization, which seem straightforward and compelling and which therefore require relatively little discussion. All of the arguments advanced here work to support the changes that have taken place through judicial innovation. That is, they justify the partial contractualization that has led to the 
hybrid that now exists. But they do more than that. They also support a move to complete contractualization. The reader should therefore bear in mind the dual purpose of this section; it is both retrospective and prospective.

\section{B. ARguments for Contractualization}

\section{The History of the LeASe as PROPERTY AND the Changed CONTEXT OF THE MODERN LEASE}

One of the assumptions about leasehold law, an assumption made both explicitly and implicitly, is that it has always been based historically on property concepts. From this assumption it is but a small step to the conclusion that lease law is inseparable from those concepts, such that leases without "property" would no longer be viable. Perhaps not surprisingly, courts and legislators have tended to see it as difficult to overturn such an entrenched and pervasive conceptual approach - like suddenly deciding that the system of estates on which land law is predicated can somehow be replaced by some other system. In fact, the history of the leasehold in the common law demonstrates that the lease has not always been seen as a conveyance, or as property. Rather, it started life as a purely contractual concept and only later became associated with property relations. Because the history of the lease demonstrates contingency and change, historical arguments do not support any particular legal approach.

This historical review does not, of course, mandate or even directly support the contractualization of the lease. But it does suggest that contractualization is not conceptually foreign to the leasehold relationship. Moreover, as we suggest in the last part of this subsection, the modern lease continues to be subject to historical change; the context and purpose of the lease has changed, and the best way to reflect that change is through the complete assimilation of the lease with contract law.

The original "commercial character" of the lease was contractual. ${ }^{137}$ The lease was a contract, initially created as a means of circumventing the Church's prohibition of usury. As Hicks has explained, " $A$, in consideration of a lump sum amount of money, would grant a term of years to B of sufficient duration to allow B to recoup both his consideration and a profit" from the use of the land. ${ }^{138}$ The lump sum was called the "premium," but was not actually a repayable loan. This transaction has been termed a "beneficial lease," and contrasted with the "husbandry lease," or the "agriculture" lease, which developed later. ${ }^{139}$

This section on the history of the leasehold is based principally on W.M. McGovern, "The Historical Conception of a Lease for Years" (1976) 23 U.C.L.A. L. Rev. 501 at 501; H. Lesar, "Landlord and Tenant Reform" (1960) 35 N.Y.U. L. Rev. 1279; J.A. Humbach, "The Common-Law Conception of Leasing: Mitigation, Habitability, and Dependence of Covenants" (1983) 60 Wash. U.L.Q. 1213; T. Plucknett, A Concise History of the Common Law, 5th ed. (London: Butterworths, 1956) at 57173; F. Pollock \& F.W. Maitland, The History of English Law, vol 2, 2d ed. (Cambridge: Cambridge University Press, 1923); J.F. Hicks, "The Contractual Nature of Real Property Leases" (1972) 24 Baylor L. Rev. 443 at 448. 
In medieval civil procedure, actions relating to property were divided into real actions, whereby a plaintiff could get recovery of the land, and personal actions, whereby a plaintiff would be awarded only damages. The conceptual division between realty and personalty - land and chattel — stems from this procedural distinction. Under a "beneficial lease," the lessee's interest was not protected by a real action. If the lessee was ejected, an action lay against the lessor alone for damages for breach of covenant. There was no action against the ejector as such. Some commentators attribute this restriction to a medieval antipathy towards money lending, or to the application of the Roman legal doctrine of possession. ${ }^{140}$ It is more likely, however, that it stemmed from the problem of double liability. The third party ejector would otherwise have been subject to actions by both the lessee and the lessor. ${ }^{141}$

With the increasing use of agricultural tenancies over terms of years, the need to protect the tenant from ejectment became more apparent. The lessee's position was changing "from that of a landholder having mere status, albeit protected, to that of a landholder having recognized contractual rights."142 Such contractual rights were in personam rights, good against the lessor and his or her heirs or assignees, and by the early thirteenth century they would allow the ejected lessee to regain possession by enforcing the covenants of the lease. ${ }^{143}$ Such rights, however, stood in marked contrast to the in rem rights of a real action. In rem rights were held by freeholders of estates, and would have protected the lessee against interference by the world at large. It was that sort of protection which agricultural tenants required. But as one commentator notes, "protection of tenants' reasonable expectations could not be drawn from the then nonexistent modern theory of contract." 144

Another solution had to be found, and by 1500 the interest in a leasehold came to be regarded not merely as "a right of action resting on a covenant," but as "a right of property." 145 The more sinister explanation for the old procedural restriction against real actions by a lessee (the creation of a punitive disincentive to money lending) would explain this change by suggesting that, once the economic purpose of the lease had changed from loan security to agriculture, the old restriction lost its conceptual moorings. ${ }^{146}$ Even without that explanation, it is clear that the restriction had become ill-suited to the actual functioning of the lease. Consequently, the lease was now regarded "primarily as a conveyance of land which was subject to property rather than contract law." ${ }^{147}$ Some commentators suggest that this development was not really required, ${ }^{148}$

See variously Plucknett, supra note 137 at 572; Hicks, supra note 137 at 449; W. Holdsworth, $A$ n Historical Introduction to the Land Law (Oxford: Clarendon Press, 1927) at 19.

See McGovern, supra note 137 at 501, 505.

Hicks, supra note 137 at 448 . See also $H$. Lesar, "The Landlord-Tenant Relation in Perspective: From Status to Contract and Back in 900 Years?" (1961) 9 U. Kan. L. Rev. 369.

See Lesar, supra note 137 at 1279; Pollock \& Maitland, supra note 137 at 109. The action quare ejecit infra terminum gave the lessor recovery against the lessor and his assignees.

Humbach, supra note 137 at 1221.

Hicks, supra note 137 at 450 .

Ibid. at 503.

K.J. Sophie, "Landlord-Tenant: The Medieval Concepts of Feudal Property Law are Alive and Well in Leases of Commercial Property in Illinois" (1977) 10 John Mar. J. Prac. \& Proc. 338 at 341. 
but required or not, the characterization of the lease as conveyance was established. The principal point for us is that the idea of conveyance had been grafted onto a contractual basis, as a contingent response to a particular problem.

The third phase in this development, the obscuring of the contractual aspects of the lease by the conveyance aspects, was likely simply the result of an accident of timing. As Lesar argues, "the doctrine that a lease is a conveyance and the rules based thereon were established before the development of the concept of mutual dependency in contracts."149 The reason that ordinary breach of contract doctrines did not apply to the lease was that the lease had, in effect, solidified conceptually before those doctrines had developed.

What this historical review suggests is that the "traditional" nature of lease law developed partly as a result of specific responses to specific historical conditions and partly by accident. Neither explanation, we would suggest, requires that we continue with the law handed down to us. Thus the next step in our argument is that as the context and purpose of the lease has changed, so too should change the dominant paradigm governing the law.

It is common to see the proposition advanced, in cases and commentary, that the property-based conception of the lease is outdated or obsolete, having "little logical relevancy for today's landlord and tenant realities."150 One can find this suggestion as long ago as 1925; McCormick made it in an article reviewing remedies available to landlords on tenant abandonment. ${ }^{151}$ There he described the lease as, in part, "a contract or agreement imposing personal obligations." 152 McCormick then suggested that a noncontractual approach would be anachronistic. Such an approach would employ a theory of obligations "springing from the relation of lord and tenant."153 That theory, he argued, would depend upon an estate-based conception of the lease which was now obsolete. "The notion of "privity of estate,"' he explained, "appears as quaint and startling as a modern infantryman with a cross-bow. The ancient weapons, reshaped though they have been in the attempt to fit them for modern uses, will at some future day, one conjectures, be altogether thrown aside."154 A lease which was interpreted without the application of contract law was ill-suited to modern demands.

"The medieval functional antecedents to modern contract law ... could have been extended or supplemented to provide much of the desired protection": Humbach, supra note 134 at 1221, n. 35. See also S. Williston, A Treatise on the Law of Contracts, 3d ed. (Mount Kisco, N.Y.: Baker, Voorhis, 1957) $\$ 890$ at 585: "As an original question, a lease might well have been regarded as a wholly bilateral agreement by which the lessor instead of making a conveyance, promises a continuing permission to occupy the premises."

Supra note 137 at 1281 . See also Hicks, supra note 137 at 454.

Interim Report on Landlord and Tenant Law Applicable to Residential Tenancies (Toronto: Ontario Law Reform Commission, 1968) at 56. See, inter alia, for similar comments, Sophie, supra note 147 at 358; R.H. Kelley, “Any Reports of the Death of the Property Law Paradigm for Leases Have Been Greatly Exaggerated" (1995) 41 Wayne L. Rev. 1563 at 1571.

C.T. McCormick, "The Rights of the Landlord Upon Abandonment of the Premises by the Tenant" (1925) 23 Mich. L. Rev. 211.

Jbid. at 216.

Ibid. at 221.

Ibid. at 222. 
But what exactly does this notion of the "obsolescence" of the law mean? We would suggest that it is made up of two related ideas, of which the second is the most important. First is the notion that a commercial lease is now as much a contract for the sale of a particular good as is any other contract for the sale of goods. The good in this case is the use of land for a period of time. But it is still simply a good not unlike any other, and its lack of permanence, the fact that title is not passed, makes the notion of the lease as a conveyance inapplicable.

Second, and more importantly, is the notion that the lease is more than a conveyance of land, more than a contract for the use of land, but a package of rights and obligations in which use of land forms but one part. Thus, in the words of Laskin J. in Highway Properties, "[i]t is no longer sensible to pretend that a commercial lease ... is simply a conveyance and not also a contract." iss Or, as suggested by Willard Estey in a comment on the Goldhar decision, "the growth of the principles of law has lagged behind the customs and practices of the commercial community." 156 Perhaps the best, and certainly the most sustained, invocation of this theme comes in the judgment of Wright $J$. in the famous American case of Javins v. First National Realty Corp. He noted that courts "have a duty to reappraise old doctrines in the light of the facts and values of contemporary life." ${ }^{57}$ The law, he suggested, should reflect the reality it governs. Wright J. noted the discrepancy between traditional and modern uses for the lease:

The assumption of landlord-tenant law, derived from feudal property law, [was] that a lease primarily conveyed to the tenant an interest in land ... [and that] the value of the lease to the tenant is the land itself. But in the case of the modern apartment dweller, the value of the lease is that it gives him a place to live ... [and] a well known package of goods and services. ${ }^{158}$

The modern tenant has little interest in the land itself, especially not in its agricultural value. Instead, the tenant generally requires space in a building and a package of services which includes the provision and maintenance of heat, light, ventilation and other amenities. Consequently, traditional property-based rules are "inappropriate for today's transactions." 159 The resolution of the discrepancy, Wright J. concluded, could be achieved through the application of contract law to leases.

Jovins dealt with a residential lease, but the theory applies with arguably even greater force to commercial leases, and indeed has been so applied. ${ }^{160}$ One only has to substitute

Supra note 5 at 721.

W.Z. Estey, "Remedies of the Landlord for the Recovery of Rent, and on Non-Payment of Rent Generally" in Law Society of Upper Canada, Special Lectures, The Lease in Modern Business (Toronto: De Boo, 1965) at 149.

428 F.2d 1071 (D.C. Cir. 1970) [hereinafter Javins] at 1074.

lbid.

Ibid. at 1075.

See, inter alia, Cain Partnership, supra note 130 at 458,459 . Reid J. noted "the failure of these traditional common law rules of property law to accommodate present business conditions." Accordingly, "[t]he parties' rights and liabilities should turn on ... rules which are consistent with modern business practice." Reid J. then applied the contractual principle of mutuality to allow the landlord to terminate and to seek damages for the tenant's non-performance. 
the assertion that "the modern apartment dweller" values a lease because "it gives him a place to live ... [and] a well known package of goods and services" with a statement that the "modern shopkeeper or manufacturer or other consumer of office space" values a lease because "it gives him a place to do business ... [and] a well known package of goods and services." That package is differently constituted, and the importance of the interest a place to do business rather than a place to live - may be less in most people's minds, but for current purposes those differences are not material. They are certainly not nearly as important as the differences between either a place to do business or a home on one hand, and agricultural land on the other.

The key to the distinction is that in an agricultural lease the land itself was everything. In a residential or commercial lease that "package of goods and services" is much more important. The package includes not just tangible and material benefits (the use of the space itself, heat and other utilities, parking, etc.) but also less tangible contractual rights (covenants to clean and repair, non-competition covenants, etc.). This is essentially what Douglas J. of the United States Supreme Court, dissenting, meant when he said in Lindsey v. Normet that the "ancient notion that a lease is a conveyance of an "estate in land," in which covenants are independent, "was appropriate in the feudal culture in which property law evolved. But this feudal notion of landlord-tenant law ... has not been a realistic approach to landlord-tenant law for many years."

This argument has also been adopted by commentators. ${ }^{162}$ Sophie notes the "radical change in the elementary purpose and design of the typical lease transaction," and concludes that traditional property-based rules have now become "impractical and inherently unfair." Property-based rules in this area, he concludes, are "out of touch with reality."163 Kelley speaks of the "obsolescence of the property law paradigm" and suggests it be given a "suitable burial." Such a "burial" would consist of "reform to reflect the realities of modern society." 164 Those realities, suggests Hicks, include the development of the "business lease," in place of the "agrarian lease." That development, he notes, "has caused an increased significance to be placed on the structures located on leased premises - their quality, condition, maintenance and terms of use."165

These arguments, then, suggest that the context and purpose of the lease has changed over time. From a conveyance of an estate, the lease has become a contract for space and for a package of services. The law should acknowledge and reflect this change by applying contract-based principles to leases. It already does so, in the sense that for some time now common law courts have construed terms in commercial leases using the same

Supra note 120 at $86-87$.

In addition to the authors quoted below see also generally B.J. Smith, "Tenants in Search of Parity with Consumers: Creating a Reasonable Expectations Warranty" (1994) 72 Wash. U.L.Q. 475.

Supra note 147 at 353.

Supra note 150 at $1564,1571$.

Supra note 137 at 451 . See also Smith, supra note 126 at 557: "In the modern lease, the structures and support services associated with the structures are more important than the land itself." These changes, he argues, point to contractualization: "With these changing expectations and the needs of landlords and tenants for a more flexible framework ... the pendulum is swinging back towards applying contract principles." 
techniques as those employed in other commercial contracts. ${ }^{166}$ Treating the lease itself as a contract would simply extend this practice, and bring formation doctrine in line with interpretive canons.

\section{INTENTION, EXPECTATION, AND FREEDOM OF CONTRACT}

Our second argument for contractualization, partly related to the historical review above, focuses on the intentions of the parties to a lease. It is based in part on a criticism of traditional lease law made by Chase and Taylor. They argue that property analysis has an "inhibiting effect" on "the freedom of courts to assess transactional facts in lease cases." 167 These "transactional facts" matter because they guide the court in arriving at the intention of the parties, which is not always clear from the contractual instrument itself. As the authors explain, "the quoted language alone is not, and should not be regarded as, sufficient to determine what the parties' expectations were at the time of the agreement." ${ }^{168}$ A property analysis is not sufficiently flexible to address transactional facts, because it is based on a "need to fit fact patterns into rather limited property law categories." ${ }^{169}$ Consequently, Chase and Taylor conclude that "conveyance reasoning can impede the free imposition of constructive conditions to effectuate the parties' expectations." ${ }^{170}$ A property-based analysis of the lease does not recognize the intentions of the parties to the deal. That is, "[i]n property law, when the landlord makes a specific promise in the lease, the significance of that promise is not assessed factually but rather conceptually." So, for example, property law regards all lease contracts as involving a possessory interest, which is conceptually defined. ${ }^{171} \mathrm{~A}$ contract analysis, by contrast, proceeds "on the strength of the facts of the case, rather than by way of deductions from a concept." It then evaluates disputes based on whether that interest has been maintained. Contract law will "inquire into the bargain actually struck by the parties as revealed by the facts and circumstances of the individual case." It will then be guided by the parameters of that bargain. ${ }^{172}$

Chase and Taylor do not take the point to its full conclusion because they prefer to maintain both property and contract approaches. Arguably, however, there is a point about freedom of contract which could be made here in support of contractualization. In a freedom of contract domain, the law respects the freedom of the parties to make their own deal because it presumes that the parties know best how to satisfy their needs. As the historical context of the lease has changed, so have parties' expectations and intentions. As one commentator concludes, "[ $t]$ he entire body of contract law, and only contract law" should be applicable to leases, since "[t]he construction of leases under the contract law

See generally M. Biles, "The Shift Towards a Commercial Interpretation of Leases - Hunting for Allegories on the Banks of the Nile," in Jackson \& Wilde, supra note 97 at 285.

Supra note 123 at 673.

Ibid. at 674.

Ibid. at 675.

Ibid. at 641 .

Ibid. at 613. See also Wood v. Lucy, Lady Duff-Gordon, 222 N.Y. 88 (1917) at 90-91, which Chase \& Taylor quote at 671, n. 356.

Chase \& Taylor, ibid. at 613, 632. 
paradigm is consistent with the expectations of the parties." ${ }^{173}$ Freedom of contract is what makes those expectations - and the demand that they be respected - legitimate. To the extent that the traditional property regime has prevented the law from effecting the parties' bargain, it has been inconsistent with their freedom. Perhaps ironically, traditional lease law has recognized this, and has partly compensated for it by permitting the use of implied terms doctrine in agreements to lease. ${ }^{174}$

Here it might be objected that the recent trend in contract law has been away from regarding the intentions of the parties as the basis for enforcement, and toward external considerations, such as fairness and justice. ${ }^{175}$ But in truth this seems a more suitable paradigm for contracts for residential accommodation, or for consumer contracts, than it does for commercial leases. It can still be argued that contractualization, based on changing historical context, would better recognize the liberty of the parties to make the deal most in accordance with contemporary needs. Indeed, it could be argued that those courts which seek to assess whether an agreement is a lease or a licence by looking at the language of the "lease" document, rather than by engaging in the often circular and fictional search for whether exclusive possession is granted, are seeking to put into effect the parties' intentions - at least to the extent of letting the parties, rather than the court, choose which legal regime will bind them. ${ }^{176}$

It might also be objected that, while the general policy of contractualization in commercial leases assumes that landlords and tenants are sophisticated actors who can bargain for their own terms, this will not always be the case. But conceding that point does not necessarily militate against the closer scrutiny of "transactional facts" associated with contractualization. The contractual doctrine of unconscionability deals with inequality of bargaining power, ${ }^{177}$ and there is no reason that the doctrine would not apply to leases. Moreover, contractualization might even help the tenant who was not able to bargain for a conditional estate to escape the consequences of serious landlord breaches. While one does not need the kind of statutory protections which society recognizes are necessary for residential tenancies, some form of informal protection, in the form of fundamental breach, will bring relief in more egregious circumstances. As the Manitoba Law Reform Commission has recently put it, "[t]enants who are in an inferior bargaining position cannot negotiate terms in their leases which would allow them to terminate their leases for serious breaches by their landlords.... [This] is an issue which calls out for reform." ${ }^{178}$ Sophie makes much the same point albeit in a different context: "[N]ot every

Kelley, supra note 150 at 1604.

See infra, text accompanying notes 201-204.

Chase \& Taylor, supra note 123 at 618, n. 135.

The leading "language" case is Metro-Matic Services v. Hulmann (1973), 48 D.L.R. (3d) 326 (Ont. C.A.). We are not, of course, referring to residential tenancies here, as almost all provincial statutes provide a functional definition of a residential tenancy and avoid the lease-licence distinction: see, for example, Tenant Protection Act, S.O. 1997, c. 24, ss. 1-3.

For the most recent statement as to when unconscionability will be found (which stresses that the crucial issue is inequality of bargaining power), see Hunter Engineering v. Syncrude Canada (1989), 57 D.L.R. (4th) 321 (S.C.C.).

Manitoba Law Reform Commission, Fundamental Breach and Frustration in Commercial Tenancies (Winnipeg: The Commission, 1996) at 11-12. 
commercial tenant has the benefit of a negotiated lease, [so] the implied warranty theory should be extended to both the residential and the commercial tenant alike."179

In short, contract law has long left behind a rigid reliance on caveat emptor as part of its underlying notion of freedom of contract. Indeed, it might be said that the property regime for leases retains more of this principle than general contract law. Through implied terms and "transactional facts," modern contract law respects the legitimate expectations of the parties. There is no reason why commercial lease law should not do the same.

\section{ECONOMIC EFFICIENCY}

The two arguments presented to this point seem to us the strongest arguments for complete contractualization. But there are two others we think worth briefly mentioning. First, there are economic efficiency arguments in favour of complete contractualization. The economic rationale for a general duty to mitigate (for example, that it is inefficient for injured parties to passively run up economic losses) applies as much to landlord-tenant relations as to any other area. ${ }^{180} \mathrm{~A}$ duty to mitigate would also be in the landlord's best interests; he or she would be better off having control of abandoned premises, able to maintain their condition and to deal with security concerns.

Efficiency arguments also support the idea that land should be used as productively as possible. As the Colorado Supreme Court said in Schneiker, "[p]ublic policy also favors the application of contract principles.... [I]t is generally in the interests of society that property be put to practical use so far as is economically feasible."181 The theory of efficient breach is apposite here. Contract law does not, as a matter of policy, compel adherence to contracts, but allows breaches so long as the losses of the non-breaching party are compensated. ${ }^{182}$ Efficient breach theory suggests that "promisors who breach increase society's welfare if their benefit exceeds the losses of their promisees." ${ }^{183}$ In the landlord-tenant context, there may be cases where, for example, abandonment by the tenant in favour of more profitable premises will allow him or her to compensate the

Supra note 147 at 355-56. See also T.R.A. Faust, "Dependent Covenants in Commercial Leases: Hindquarter Corp. v. Property Development Corp." (1985) 8 U. Puget Sound L. Rev. 485 at 507: "Relative bargaining power is another policy rationale" that has led to dependent covenant decisions. See the expression of this idea in Schneiker, supra note 124 at 610: "In no other context ... is an injured party permitted to sit by idly and suffer avoidable economic loss." See also Smith, supra note 126 at 561: "There are sound, practical policy reasons for applying contract rules to the leasehold area ... [including that fact that] the rules for awarding damages discourage wronged parties from passively suffering avoidable economic losses." See also Shaw, supra note 113 at 230 and passim. Supra note 124 at 610 . See also Reid, supra note 132 at 905 : There are "policy arguments in favour of the modern [contract] rule," such as that "the economies of both the state and the nation benefit from a rule that encourages the reletting of premises, which returns them to productive use." The exception to this, of course, is specific performance; but it is a limited exception, and its scope has recently been even further reduced by the Supreme Court of Canada, which has held that land should no longer be automatically seen as unique and that the intention of the parties should matter more: for a discussion see infra notes 218-19 and accompanying text.

P. Linzer, "On the Amorality of Contract Remedies - Efficiency, Equity and the Second Restatement" (1981) 81 Colum. L. Rev. 111 at 114. See also generally R. Posner, Economic Analysis of Law, 2d ed. (Boston: Little Brown, 1977) at 88-90. The theory is not without its critics: see I.R. Macneil, "Efficient Breach of Contract: Circles in the Sky" (1982) 68 Va. L. Rev. 947. 
landlord and to profit from the move. The breach would thus represent a net gain to the economy. Complete contractualization of commercial lease law would promote economic efficiency by allowing such efficient breaches to occur more easily than under the current law.

\section{Conceptual Clarity: The Lease is an ExeCutory CONTRACT}

An essential element of the conceptual underpinnings of the traditional "property" nature of the lease is the idea that the lease is an executed contract. That is, once the term has begun and the tenant has entered into possession, the contractual relations between the parties are ended. The contract (the agreement to lease) has been executed, and the whole subject matter of that contract (the estate) has been conveyed from one person to another, just as with a contract for the sale of freehold land. ${ }^{184}$ The concept of execution, Waddams explains, "applies primarily to a contract, such as one of sale or lease, where property is to be transferred." 185 From this spring the doctrines we have already discussed, such as the idea that fundamental breach cannot be applied to leases. The notion of the lease as an executed contract means that there is no ongoing contract to be breached.

As elegant as this conceptualization is, however, the fact remains that the idea of a lease as an executed contract makes little intuitive sense. Courts and commentators have recognized the practical unreality of categorizing the lease wholly as an executed contract, and have in consequence suggested various ways to deal with the contradiction involved. The promise to pay rent, for example, has been explained by analogy with an instalment payment for something purchased on credit; the purchase contract is executed, but the liability for the payments persists. ${ }^{186}$ To similar effect, we often find the lease being described as both an executed and an executory contract, ${ }^{187}$ despite the logical impossibility of such a characterization. The lease is a singular contractual instrument it cannot be both executed and executory at once. If any part of the lease contract remains unperformed, the contract remains executory, notwithstanding the fact that an interest has been transferred. ${ }^{188}$

It is time to recognize the essentially executory nature of the lease, and we offer two related reasons for this. First, at the heart of a lease is a continuing relationship between landlord and tenant, a relationship in which the right to use space is regularly transferred

184

See one example of the classical position in White v. Molyneux, $2 \mathrm{Ga} .124$ (1847) at 128, in which it is stated: "The contract is an executed one; the tenant is in the position of a purchaser of the premises for the term."

185

The Law of Contracts, 4th ed. (Toronto: Canada Law Book, 1999) at 304.

See Siegal, supra note 70 at 657 . For a discussion see generally Chase \& Taylor, supra note 123 at 637.

See Progressive Mailing, supra note 108 at 51 , describing the lease as "both an executory contract and an executed demise."

A variation on this point is that, even where part of an interest has been transferred under the lease prior to the end of term, the whole term has not in fact been executed. In reality, therefore, notwithstanding the fact that an interest has been transferred, the lease is as much executory as it is executed: see Weinrib, supra note 24 at 544-45. 
for payment of rent. It is a continuous, ongoing exchange of proprietary values within an essentially contractual framework. Coupled to this primary transfer are a series of additional contractual bargains, in which other duties and liabilities are contractually assigned. As one commentator puts it, "the modern lease ... is a continuing contractual relationship between the lessor and the lessee." 189 The lease is thus an executory, or "instalment" model, contract.

Second, it is necessary to recognize that whatever concepts are employed, the doctrinal changes to commercial lease law that have already taken place have severely undermined both the pure conveyance model and the hybrid idea. Here we can use the fundamental breach example, for that doctrine simply cannot be adequately explained by the executed contract model. A fundamental breach occurs when a party to the contract is deprived of substantially the whole benefit intended under the contract that he or she should receive. ${ }^{190}$ If the principal obligation under a contract is executed, the obligor has substantially performed. Unperformed covenants may yet be breached, but if the contract has been executed, no subsequent breach will be fundamental. ${ }^{191}$

Other examples could be given, but this is sufficient to make our point. The point is a simple one - the reality of the lease is that it looks, smells, and sounds like an executory contract. But it remains classified as executed, and that in turn produces conceptual confusion and not a little analytical legerdemain. There is no need to retain any aspect of the execution characterization.

\section{The Consequences of Complete Contractualization}

\section{A. General}

This article began by laying out a limited number of ways in which judicial innovation has altered the essential nature of the lease, modifying the estate conception to produce a hybrid of property and contract. It then argued that those changes were beneficial and that in general the lease ought to be entirely re-conceived as an ordinary commercial contract for the sale of a good like any other - in this instance use of space for a term. In other words, all aspects of lease law, not just the areas of abandonment and independence of covenants discussed in Section II, ought to be contractualized; partial contractualization should be expanded to complete contractualization.

See Chew, supra note 108 at 100 . See also this exceptional characterization from one nineteenth century American case, which stated that a lease is "a running rather than a completed contract," and "an agreement for a continuous interchange of values between landlord and tenant, rather than a purchase single and completed of a term or estate in lands": Whitaker v. Hawley, 25 Kan. 674 (1881) at 687.

190 See Hongkong Fir Shipping Co. v. Kawasaki Kisen Kaisha, [1962] 2 Q.B. 26.

191 Corbin puts it this way: "Upon the execution of the lease, the landlord has conveyed and the tenant has received a property interest in the land. In making this conveyance, the landlord has rendered the most important of the performances that the parties contemplate in connection with the lease. Subsequent breaches of covenant by him, therefore, do not operate as a total failure of consideration": A.L. Corbin, Corbin on Contracts, vol. 3A (St. Paul: West Publishing, 1960) at 240. See to similar effect Stollery, supra note 3 at 259. 
In this final section we review, for the most part necessarily briefly, what the further consequences of that expansion would be. We do so by examining a number of areas of current commercial lease law, pointing out what would change with contractualization and suggesting that such changes would be either beneficial or, in some instances, neutral. In this review we spend the most time on the issue of security of tenure for the tenant, which seems to us to pose the greatest obstacle to complete contractualization.

Before we enter a discussion of specific doctrines, however, we should make clear that this last section is necessarily somewhat abstract, unlikely to serve as a practical prescription of what courts might be willing, or indeed able, to achieve. That is, while there are some doctrines of current commercial lease law which are susceptible to judicial innovation in the same way that the areas discussed in Section II have been (frustration comes most obviously to mind) there are others which it is very difficult to imagine a court could, or would, alter. Distress, for example, which we see as an anachronism, is now largely statutory, ${ }^{192}$ and it is therefore not feasible to argue that a court could bring about its abolition. Some of the changes we propose, therefore, are matters which can only be achieved by a comprehensive package of legislative reforms. Moreover, it may well be that some of the solutions that we advocate, especially those in the final section dealing with security of tenure and third-party rights, will be seen by some as unnecessarily complicated, with the current (or extended) hybrid preferable. We acknowledge both of these objections, but we also do not see them as fatal to the exercise of thinking through the consequences of complete contractualization.

In this section we suggest that there are four features of traditional commercial lease law that contractualization will, and should, alter. First, and this is perhaps the easiest and most obvious case, it should be confirmed that the doctrine of frustration applies to commercial leases, as it does, by statute, to residential tenancies. ${ }^{193}$ As we have seen, the House of Lords has already held that frustration may apply, although it suggested that it rarely would. ${ }^{194}$ Canadian cases have by and large followed the traditional viewpoint that frustration does not apply, citing the standard explanation that the tenant still has the estate even if, for example, the premises are destroyed. ${ }^{195}$ This is obviously not in tune with modern commercial reality, a fact recognized by the British Columbia legislature, which has made frustration applicable to commercial tenancies. ${ }^{196}$

192 While distress was a product of the common law of leasehold relationships, all provincial statutes now contain numerous provisions on it. While none of these statutory provisions "establish" distress (merely regulate it and alter some of the common law rules), they would surely be seen as a legislative sanction of distress, and therefore this is not an area for curial innovation. For typical distress provisions, see Ontario's Commercial Tenancies Act, supra note 63, ss. 30 et seq.

See, for example, Ontario's Tenant Protection Act, supra note 176, s. 10; Residential Tenancies Act, R.S.A. 1980, c. R-15.3, s. 32.

195 See, e.g., Merkur v. H. Shoom \& Co., [1954] 1 D.L.R. 85 (Ont. C.A.); Foster v. Caldwell, [1948] 4 D.L.R. 70 (N.B.C.A.); Vancouver Breweries v. Dana \& Fullerton (1915), 52 S.C.R. 134; Binder v. Key Property Management Corp. (1992), 26 R.P.R. (2d) 80 (Ont. Gen. Div.). The Ontario Court of Appeal has held that frustration applies to contracts for the sale of land, despite the fact that equitable title passed to the purchaser when the contract was signed: see Capital Quality Homes v. 
Second, complete contractualization will have some effect on the law relating to implied covenants and implied terms in leases. Currently the common law, in the absence of lease terms to the contrary, implies three covenants into every lease: the covenant for quiet enjoyment and the covenant against derogation from grant apply to landlords, while the tenant is bound by the requirement that he or she act "in a tenant-like manner" and essentially take care of the premises. ${ }^{197}$ But the common law does not generally imply a covenant that the premises will be fit for the purposes for which they are to be used; this is only applicable in the case of furnished premises, and thus has little application in commercial leases. ${ }^{198}$ Contract law, in contrast, implies a warranty of fitness for use in all commercial transactions where the buyer informs the seller of the intended use in such a way as to indicate reliance on the judgment of the seller, and where such a warranty is not explicitly disclaimed. ${ }^{199}$

Generally, tenants will benefit from this move to contract; both the existing implied covenants would surely fall within the ambit of a general fitness for use warranty, ${ }^{200}$ and all tenants would be treated the same, the illogical furnished/unfurnished distinction being abolished. There seems no obvious objection to this, especially when one remembers that a large part of the common law objection to a warranty of fitness was the difficulty of providing for it in long leases of agricultural land. With the changed character of the modern lease, it is both possible and reasonable to enforce such an obligation. The covenant to act in a tenant-like manner would not, of course, be included in a warranty of fitness, and would thus be eliminated. The practical effect of that, however, would be nugatory, for almost every commercial lease displaces the covenant by explicitly delineating repair obligations.

Similarly, complete contractualization would mean that the contract doctrine of implied terms would fully apply to leases. ${ }^{201}$ This doctrine permits courts to imply terms in order to give "business efficacy" to agreements, provided each party could reasonably have taken the other to be agreeing to the particular bargain. ${ }^{202}$ It is more than likely that the doctrine already applies to leases, in that implied terms are an issue in the formation of the lease, the contractual, pre-conveyance, stage of the relationship. As one text puts it, such an implied term is "a covenant found and implied as a matter of fact and

See generally Ziff, supra note 32 at 268-71; Stollery, supra note 3 at 242-55.

See Davey v. Christoff (1916), 28 D.L.R. 447 (Ont. C.A.), which also reviews the mid-nineteenth century English cases that established this distinction.

See Gardiner v. Gray (1815), 4 Camp. 144, 171 E.R. 46. This common law rule has long been given statutory sanction: see, inter alia, Sale of Goods Act, R.S.O. 1990, c. S-1, s. 15(1); Sale of Goods Act, R.S.B.C. 1996, c. 410, s. 18(a); Sale of Goods Act, R.S.A. 1980, c. S-2, s. 17.

Certainly the covenant against derogation from grant would do so, for it protects tenants from actions by the landlord which render the land substantially or materially less fit for the purpose for which it was let: see generally Harmer v. Jumbil (Nigeria) Tin Areas, [1921] 1 Ch. 200 (C.A.). And it is likely that the covenant for quiet enjoyment would do so also, for it likely "extends to any conduct of the landlord or his agents which interferes with the tenant's freedom of action in exercising his rights as tenant": see McCall v. Abelesz, [1976] 1 All E.R. 727 at 730-31 (C.A.), per Lord Denning. For a discussion of this issue see Stollery, supra note 3 at 256-57.

See The Moorcock (1889), 14 P.D. 64 (C.A.); Smith v. Hughes (1871), L.R. 6 Q.B. 597; Waddams, supra note 185 at 357. 
not a covenant implied by law from the mere relation of the parties as landlord and tenant. ${ }^{, 203}$ But there is nonetheless language in some implied terms in leases cases that suggests that this kind of implied term is a "collateral contract" to the lease, not part of the lease itself. ${ }^{204}$ While the better view is probably that it should be considered part of the lease, contractualization would clear up this point.

The third area that would be substantially affected by contractualization is the alienability of the tenant's interest. ${ }^{205}$ Under the property conception of the lease the fact that a tenant has an estate means that it can be conveyed to others, either by assignment (granting the whole term to another) or by sub-letting (granting any period of less then the whole of the remaining term to another). At common law, landlords can limit this right by an absolute or partial (a requirement of consent to any transfer) prohibition. ${ }^{206}$

With complete contractualization the content of the law regarding sub-contracting would be substantially unchanged - the right to sub-let would simply be a right to subcontract, and would be inherent unless the contract specified otherwise. With regard to assignment, however, the situation would change, at least formally. A tenant under a contractualized lease, as a mere licensee, would no longer have an inherent power to assign as a matter of property law, because the landlord would not be bound by such an assignment. ${ }^{207}$ And contract law would not fill the void, because while contractual rights are generally assignable ${ }^{208}$ contractual liabilities are not, and we assume that a tenant is more like a debtor than a creditor in this regard. Contractual liabilities may only be made assignable by the terms of the contract or by consent of the entitled party. ${ }^{209}$ With a contractualized lease, therefore, assignment will no longer be an inherent right.

However, if we remember that under property rules the landlord could usually forbid assignment and sub-letting, it seems reasonable to say that the tenant would be no worse off under contract law. The default rule has changed, from an inherent right to assign to no such right, but in both cases it is only a default rule, and the parties' bargain may

C. Bentley et al., Williams and Rhodes Canadian Law of Landlord and Tenant, 6th ed. (Toronto: Carswell, 1988) at 3-44.

See, e.g., Brymer v. Thompson (1915), 23 D.L.R. 840 at 842 (Ont. S.C.). not change that in any way, so that issue is not discussed here. The consequence of such alienation for tenants is discussed in the following section.

See generally Ziff, supra note 32 at 258 ; Bentley, supra note 203 at 15-24 et seg.

R.E. Scane, "The Relationship of Landlord and Tenant," in Law Society of Upper Canada, Special Lectures, The Lease in Modern Business (Toronto: De Boo, 1965) at 3, 7.

As Waddams explains, "[a] contractual right is a species of property, and like other kind of property it can be transferred from one person to another": supra note 185 at 187 . There are exceptions, such as within personal relationships. Note also that while the history of contractual assignment is complex, the assignment of contractual rights is authorized by statute in all Canadian common law provinces: see, inter alia, Conveyancing and Law of Property Act, R.S.O. 1990, c. C-34, s. 53(1); Judicature Act, R.S.A. 1980, c. J-1, s. 21(1); Choses In Action Act, R.S.S. 1978, c. C-11, s. 2. These provisions all derive from the Judicature Act, 1873, (U.K.), 36 \& 37 Vict., c. 66.

See Tolhurst v. Associated Portland Cement Manufacturers, [1903] A.C. 414 (H.L.). The case is essentially novation, the cancellation of the old contract and the substitution between new parties of a contract containing the same terms: see J. Beatson, Anson's Law of Contract, 27th ed. (Oxford: Oxford University Press, 1998) at 462. 
override it. In essence, therefore, both property and contract regimes essentially leave this as a matter to be bargained for, and that seems right. There is no particular reason to treat alienability as different from any other term of the contract. ${ }^{210}$ Similarly, the issue of which lease terms (covenants) would be transferred to the new tenant would also be resolved by contractual bargaining. ${ }^{211}$

Having said this, however, there is one further complication. Currently, many provincial statutes modify slightly the landlord's power to prohibit transfer of the tenant's interest. $^{212}$ Typical is Ontario's statute, which provides that a covenant against assignment and sub-letting without consent shall, "unless the lease contains an express provision to the contrary, be deemed to be subject to a proviso that such ... consent is not to be unreasonably withheld." 213 Complete contractualization would remove such provisions from the law. But note how limited is this kind of protection for tenants in any event; legislation does not prevent blanket prohibitions, and it does not even require reasonableness in all "permission" covenants - only if the lease does not specifically exclude it. In other words, landlords can already oust the requirement for reasonableness of refusal. Thus, again, it can all be brought back to bargaining and contract law will likely produce a landscape very similar to estate law in this area. In fact, a tenant might be better off in contract law, for a provision reserving "sole discretion" over assignment and sub-letting to the landlord would nowadays be subject to a requirement that it be exercised "in a reasonable way." 114

Finally, in this section we consider distress, the right of the landlord to enter the tenant's premises and take goods of the tenant from those premises in order to satisfy demands for rent. ${ }^{215}$ It is obviously a highly unusual remedy; no other area of the law grants creditors this kind of self-help regime. It derives from the estate conception of the lease, specifically from the idea that the estate has been wholly granted and that rent issues out of the estate. Obviously, distress cannot live with a conceptual shift to contract, for contract law does not give any one species of contractual creditor a remedy denied to all others. But this should not be a concern. There is no reason to value this "relic of

The law, of course, is generally concerned with limiting restraints on alienation, for a variety of policy reasons. But we suggest that this is much more a concern for freehold law, because of the potential duration of such restraints, than for lease law, where there is a natural limit to the restraint - the lease term.

Currently, of course, this area is governed by the rule in Spencer's Case (1583), 5 Co. Rep. 16a, 77 E.R. 72, which states that covenants will run when a lease is assigned if they are "real" rather than personal covenants, if they touch and concern the land. Under a contractualized lease this distinction between real and personal covenants would disappear, and the issue in any case would be whether the assignor has successfully transferred the contractual obligation to the assignee. This is true for liabilities; contractual rights are generally assignable: see text accompanying notes 208 and 209. For a recent thorough review of how the courts now treat such covenants in leases, see Bankes \& Rafferty, supra note 78 at $164-76$.

Commercial Tenancies $A c t$, supra note 60, s. 23(1). Essentially the same provision appears elsewhere: see, e.g., Landlord and Tenant Act, R.S.M. 1987, c. L-70, s. 22(1); Landlord and Tenant Act, R.S.N.B. 1973, c. L-I, s. II(1).

Greenberg v. Meffert (1985), 18 D.L.R. (4th) 548 at 555 (Ont. C.A.). See also the comment, at 556, that "a discretion must be exercised honestly and in good faith." 
feudalism"216; there is no reason not to insist that landlords employ the civil courts to collect their debts like everyone else. Distress is a remedy very susceptible to abuse, as evidenced by the extensive statutory provisions which seek to carefully delineate such issues as which property may be taken, when it may be taken, what constitutes excessive distress, etc. ${ }^{217}$ Indeed, its inappropriateness has been recognized in the law of residential tenancies, from which it has been either entirely removed or substantially restricted. ${ }^{218}$

\section{B. The Problem of the Tenant's Security of Tenure}

One of the principal incidents of the traditional property conceptualization of the lease is security of tenure for the tenant for the term of the lease. The tenant possesses an estate, and the landlord cannot recover that estate except on the happening of certain events, the most common of which is a forfeiture action for breach of condition. The landlord cannot simply "breach" the lease, recover possession, and pay damages. Indeed, the law has gone further to protect tenure: construing forfeiture clauses strictly, allowing for implied waiver of rights of forfeiture, and permitting tenants to apply for relief against forfeiture in appropriate circumstances, even where a condition has been breached. ${ }^{219}$ Security of tenure, of course, is only available because the law views the lease as an executed contract conveying an estate to the tenant.

At first sight complete contractualization poses a major problem for tenants' security of tenure. Without property-based concepts, such as estate possession, forfeiture and relief against forfeiture, it could be argued that the security of the tenant's interest in the leasehold, its freedom from arbitrary termination, would be greatly reduced. As one author puts it, "[w]hat might once have been described as a 'bundle of rights' may look more like a single twig." ${ }^{220}$ Tenants need to be able to rely on the security of the term, not just for itself, but because they come generally to be identified with a particular location - they build up relations with local consumers and suppliers, sink advertising costs into the location, etc.

It is not really possible to solve this problem through public regulation of the lease contract, a statutory provision providing for security of tenure. This is the approach to residential tenancies in some jurisdictions, such as Ontario, where legislation permits the tenant to stay as long as he or she wants and provides for a limited class of exceptional circumstances that will lead to termination. ${ }^{221}$ It does this because it recognizes the

This is the phrase used in the U.K. Law Commission's Landlord and Tenant: Interim Report on Distress for Rent (London: H.M.S.O., 1966), cited in Ziff, supra note 32 at 272.

See, e.g., Ontario's Commercial Tenancies Act, supra note 63, s. 30 et seq.

See Ontario's Tenant Protection Act, supra note 176, s. 31, abolishing distress.

Relief against forfeiture was originally an equitable remedy, but is now contained in all provincial statutes: see generally Ziff, supra note 32 at 272-73. For the Ontario provisions see Commercial Tenancies Act, supra note 63, s. 20.

221 See generally Tenant Protection Act, supra note 176. Some provinces give the same kind of security (for example, British Columbia and Manitoba), while others provide a reduced version of security of tenure. Nova Scotia, for example, gives security of tenure to tenants who have resided on the 
status of the residential tenancy as a home. But in the commercial tenancies area legislation could not mandate indefinite possession, as that would make nonsensical the idea of the parties bargaining for a term in the first place. Nor could the legislation state unequivocally that agreements for possession of land for a certain term were to last for the whole of that term unless the parties agreed otherwise, for that would remove the doctrines of anticipatory and fundamental breach from contract law relating to land use. We have argued exactly the opposite - that those doctrines should be applicable. And if the legislation stated that agreements for possession of land for a certain term were to last for the whole of that term unless the parties agreed otherwise or unless there was an anticipatory or fundamental breach, it would add nothing to the common law.

In short, if we wish to provide real security of tenure to the tenant in a world of complete contractualization of leases, a solution to the security problem must be found in contract law. In fact, contract law offers three possible routes to protecting the tenant's term. First, specific performance might assist. It is trite law that specific performance is only available as a remedy for breach of contract where the good contracted for is in some way unique, where the innocent party cannot receive damages and substitute an alternative. ${ }^{222}$ Many tenants would be able to argue that having contracted for a particular space in a particular place and having advertised that location and invested in the premises and become known as doing business there, damages would not be an adequate remedy, for they have a unique good. The Supreme Court of Canada has recently ruled that orders of specific performance will no longer be awarded as of right in cases dealing with land as they once were. ${ }^{223}$ But this does not make specific performance unavailable for cases involving land; it only makes it not an automatic right. More importantly, one may well argue that the uniqueness feature which in the past decreed specific performance for contracts dealing with land is actually less true for sales than for leases. When a sale contract is breached the purchaser has not been able to invest in, or rely on, the location, for the simple reason that he or she has not used the premises. A tenant may well have done the kinds of things that make the premises unique to him or her.

The second possible solution to the problem relies on the law relating to contractual licences. With contractualization, the tenant's occupation of land will rest on a contractual licence, not on a lease. The common law always took the position that a bare licence was

premises for five years: see Residential Tenancies Act, R.S.N.S. 1989, c. 401, s. 10(8).

See generally Waddams, supra note 185 at 494.

Semelhago v. Paramadevan, [1996] 2 S.C.R. 415. At 428 Sopinka J. stated:

While at one time the common law regarded every piece of real estate to be unique, with the progress of modern real estate development this is no longer the case. Residential, business and industrial properties are all mass produced in much the same way as other consumer products. If a deal falls through for one property, another is frequently, though not always, readily available. It is no longer appropriate, therefore, to maintain a distinction in the approach to specific performance as between realty and personalty. It cannot be assumed that damages for breach of contract for the purchase and sale of real estate will be an inadequate remedy in all cases. 
revocable at any time without compensation, ${ }^{224}$ but equitable principles changed this in two important respects. First, since the mid-nineteenth century it has been accepted that equity will only permit revocation of a contractual licence in accordance with the terms of the contract, so that damages would be paid for any losses flowing. ${ }^{225}$ Second, and more importantly for our purposes, a more recent line of authority establishes that equity will prevent the revocation altogether, via injunction, if the contract expressly or impliedly includes an agreement not to revoke or limit the terms on which revocation can take place. ${ }^{226}$ This does not mean that the licence creates a proprietary interest (an issue we will discuss in more detail below); it is merely the operation of contract law principles. ${ }^{227}$ In short, tenants who are able to argue that their leases expressly or impliedly include an agreement not to revoke, or more likely an agreement not to revoke except in certain circumstances (except, perhaps, on material breach such as a failure to pay rent), will be able to prevent landlords from simply revoking their agreement. We therefore return, again, to bargaining. If a tenant wants the protection of an irrevocable licence, he or she must bargain for it. In a commercial context, this does not seem objectionable for the majority of cases.

The doctrine will not, of course, operate in all circumstances, for it will require a finding of an agreement against revocation. One might speculate that the courts will be quick to find such an implied agreement and thus this doctrine will grant the security of tenure needed. But they might not, or landlords might use their bargaining power to negative any such agreement by clear language in the contract. Thus there may be situations in which a landlord who was prepared to pay the damages would be able to terminate the contract at some time highly inconvenient to the tenant, for example, three years into a ten-year lease and just as the tenant's store is becoming established and known in the area. One might, of course, respond to that problem by saying that it is not a problem; that is, that if there is no agreement not to revoke there should be no protection against revocation: the landlord has bargained for the right to revoke. This, however, seems unreasonable, given the fact that not all tenants, even business tenants of commercial leases, will be in an equal bargaining position with landlords. Moreover, contractual licence law contains no doctrine that serves the same function as relief against forfeiture. A tenant who committed a breach sufficient to end the contract, a repudiatory

Wood v. Leadbitter (1845), 13 M. \& W. 838, 153 E.R. 351 . See also Ziff, supra note 32 at 282-85 for a general discussion of licences. Note that a contractual licence is different from a licence coupled with a grant or interest in property, which is irrevocable and assignable in conjunction with the interest. If the contractualized lease were seen as such an interest, which is not what we are arguing here, the problem would be solved.

See Thompson v. Park, [1944] K.B. 408 (C.A.); The King v. Dominion of Canada Postage Stamp Vending Co. [1930] S.C.R. 500.

This principle goes back to Hurst v. Picture Theatres, [1915] I K.B. 1 (C.A.). For more recent affirmations see Winter Garden Theatre (London) v. Millenium Productions, [1948] A.C. 173 (H.L.); Verrall v. Great Yarmouth Borough Council, [1980] I All E.R. 839 (C.A.); for Canada, Imperial Oil v. Young (1998), 167 Nfld. \& P.E.I.R. 280 (Nfld. C.A.).

The doctrine is based on the principle that the court will not use an injunction - here an injunction to remove the tenant - to assist in a breach of contract: see Waddams, supra note 185 at 457. 
breach, and whose landlord accepted the repudiation, would automatically lose its interest. $^{228}$

Something further would therefore be needed to protect some tenants who did not have the ability to contract for a non-revocation or limited-revocation contract provision, and to protect other tenants who commit a breach but who have a substantial interest in having that breach forgiven to the extent that it not lead to the loss of their entire interest. Again, these are the kinds of problems that lead some commentators to argue that the estate conception of the lease must be retained in part. Barr, for example, argues that an untrammeled right for the landlord to repudiate a lease on tenant breach would have "disastrous repercussions for the tenant's security of tenure."229

This brings us to the third possible solution to the security of tenure problem: reliance, or more particularly, detrimental reliance. Generally, detrimental reliance provides that where one party has acted to his or her detriment on the reasonable reliance of the representations of another, that other will not be allowed to go back on those representations - he or she will be estopped from doing so. ${ }^{230}$ Detrimental reliance is thus protected by estoppel. Estoppel has long been applied to land, for the oldest of the two principal forms of estoppel is proprietary estoppel, ${ }^{231}$ and there are many instances of it being used to resolve landlord and tenant disputes. ${ }^{232}$ It applies where an owner of land "requests or allows another to spend money under an expectation, created by the owner ..., that the other party will be able to remain there." ${ }^{233}$ If the other party then acts on that belief, spending money or taking other action to his or her detriment, such that he or she would suffer losses were the putative interest in land to be dishonoured, then equity will protect that detrimental reliance by preventing the inducing party from acting as though the other party does not have an interest.

Promissory estoppel, by contrast, applies where a promisor induces another to believe that the other party has acquired or will acquire some interest under the promise, and the induced party acts on that belief. ${ }^{234}$ There is some debate over whether there is any real

See Pawlowski, supra note 95 at 383. Pawlowski suggests that, in the absence of specific statutory or contractual provisions governing the recovery of possession under a contractualized lease, "a repudiatory breach by the tenant, coupled with its acceptance by the landlord, would of itself terminate the tenancy thereby rendering the law of forfeiture nugatory" [emphasis in original]. Supra note 97 at 328.

We cannot provide a substantial analysis of detrimental reliance here; for additional basic explanations and illustrations, see Waddams, supra note 185 at 136-55; Edwards v. Harris-Intertype (1984), 9 D.L.R. (4th) 319 (Ont. C.A.); Maracle v. Travellers Indemnity Co. (1991), 80 D.L.R. (4th) 652 (S.C.C.).

For the law on proprietary estoppel, see principally M. Pawlowski, The Doctrine of Proprietary Estoppel (London: Sweet and Maxwell 1996). See also M. Welstead, "Proprietary Estoppel and the Acquisition of Possessory Title" (1991) 55 Conv. 280; S. Gardner, "The Remedial Discretion in Proprietary Estoppel" (1999) 115 L.Q. Rev. 438.

See one recent case, which reviews a variety of others: Sledz v. Edmonton Home Fair (1997), 28 R.P.R. (3d) 132 (Alta. Q.B.).

Ziff, supra note 32 at 282-83.

For promissory estoppel the classic case is Hughes v. Metropolitan Railway (1877), 2 L.R. App. Cas. 439 (H.L.). 
distinction between the two types of estoppel, but that is not a matter which concerns us. ${ }^{235}$ Both reflect the same principle: detrimental change resulting from reasonable reliance on the representations of another should be prevented or protected to the extent of the reliance. What matters for our purposes is not whether an estoppel is proprietary or promissory but that, based on this principle, detrimental reliance can give rise to an irrevocable licence by estoppel even if there is no agreement not to revoke.

The case that perhaps best illustrates the operation of estoppel is Crabb v. Arun District Council, ${ }^{236}$ where proprietary estoppel was applied. The plaintiff was led to believe that, despite the absence of a formal grant, he would be given a right of way across the land which he was selling to the Council. Without the right of way, he was landlocked. After the sale, the Council denied him access. The court awarded him the easement, based on his detrimental reliance (he sold the land) on the defendant's representations (he would receive a right of way). Detrimental reliance also created a proprietary interest in the Canadian case of Stiles v. Tod Mountain Development. ${ }^{237}$ Stiles purchased a lot in a proposed sub-division from a developer, which encouraged him to build. He did so, but shortly thereafter the province rejected the plan of sub-division. As a result, Stiles and others in the same situation were left without any recognizable interest in land, because the land could not legally be sub-divided. The owner of the entirety, a company which had bought the land from another company which had bought from Stiles' original "vendor," first promised Stiles and others in the same position that they could stay, but then tried to evict them. Stiles sued and won a licence by way of proprietary estoppel a declaration of his right to remain in occupation.

The security of tenure concern can, we believe, be resolved by resort to estoppel based on detrimental reliance. Where a landlord induces a tenant to believe that the tenant will be able to stay for the full term of the lease, and the tenant acts on that belief by incurring reliance costs to his detriment, the landlord will not be allowed to go back on that promise to the extent of the reliance. ${ }^{238}$ The tenant's security of tenure under a contractualized lease may thus be protected. It would not, of course, be protected in the event of fundamental breach by the tenant, but there is no reason that it should be. It might well, however, serve as a kind of relief against forfeiture for lesser breaches; in such

For that debate see, inter alia, Pawlowski, supra note 231 at 4-6; G.S. Bower \& A.K. Turner, The Law Relating to Estoppel by Representation (London: Butterworths, 1977) at 307; M. Lunney, "Towards a Unified Estoppel - The Long and Winding Road" (1992) 56 Conv. 239 at 247-251; E. Cooke, "What Are We Going to Do About Estoppel," in Jackson \& Wilde, eds., supra note 97 at 53. Indeed the Australian High Court has recently likely merged the two: see Giumelli v. Giumelli (1999), 161 A.L.R. 473. There is also some debate in England about whether in proprietary estoppel the proprietary interest arises from the moment that the estoppel does, but as it need not do so here we are not concerned with that debate. For its contours see C.J. Davis, "Proprietary Estoppel: Future Interests and Future Property" (1996) 60 Conv. 193 at 193: "[I]n recent cases ... it would seem that [the claimant] has a right in the nature of the interest ultimately awarded to him from the moment the estoppel arises."

It is not necessary for our purposes to decide whether such an estoppel creates an interest in land. But given the shift from lease to licence that would come with complete contractualization, it would be odd to suppose that an interest in land has been created. 
circumstances the court would have to find a balance, relying on the inherently discretionary nature of equitable remedies, in precisely the same way that it balances when exercising the discretionary relief against forfeiture jurisdiction. The tenant would also not be protected if there was no detrimental reliance. That is, we are not suggesting that detrimental reliance simply stand in the shoes of the concept of conveyance of an estate; it would be possible for a landlord to breach the contract and pay compensation, just as it is should be possible for the tenant to do so. Only if there has been detrimental reliance on the security of the term will it be enforced.

There is, however, a further aspect of the security of tenure problem to be dealt with: if a landlord alienates ownership of the premises subject to the lease, will the purchaser be required to honour the contract with the tenant? Under the estate conception sale of the reversion by the landlord makes no difference to the tenant's rights. The independent possession of an estate by the tenant generates a privity of estate with any new landlord, even though there is no privity of contract, and the doctrine of priority of estates means that the tenant is in the same position against the new owner as against the old, even without privity of contract. ${ }^{239}$ But with contractualization there would be no privity of estate, only the doctrine of privity in contract law, which would mean that the tenant would have no claim against a successor owner of the premises. We call this the durability problem - the need for the tenant's rights to be durable, to be enforceable against those with whom he or she has no direct relationship. ${ }^{240}$ And this problem is, again, a serious one, leading some courts and commentators to insist on the need to retain at least some aspects of the estate conception. ${ }^{241}$

There are two possible solutions to the problem. One would be simple: a statutory provision which states that where a contract is for the use of land for a term, successorsin-title to the owner are deemed to have privity of contract with the original contracting tenant. That is, while a statutory solution would not be available for the general security of tenure problem, one could easily be crafted to deal with the third party problem.

The second solution would be for the courts to revisit the issue of whether it ought to be possible for a contractual licence to bind third parties. As already noted, complete contractualization makes the tenant a contractual licensee, and there is a long line of authority to the effect that contractual licences do not create proprietary rights against

See Scane, supra note 207 at 7 . The exception, of course, comes in the case of the person who leases from a mortgagor who is then foreclosed.

We borrow this term from J. Hill, "Intention and the Creation of Proprietary Rights: Are Leases Different?" (1996) 16 Legal Stud. 200 at 202.

See, inter alia, Barr, supra note 97 at 330-31; Shaw, supra note 113 at 244; Humbach, supra note 134 at 1220 . See also an Australian case, Kennedy Holdings \& Property Management v. Federal Commissioner of Taxation (1992), 111 A.L.R. 410 at 414, in which it was argued that a leasehold should be regarded as purely personal property, in accordance with contractualization. After noting the origins of the lease in contract and the original lack of proprietary remedies to enforce the leasehold against third parties, Hill J. rejected the argument: "[I]t is hardly an adequate description of a lease today to suggest that the benefits of a lessee depend solely upon contract and not upon the underlying estate in land which is demised.... [I]n time it had become accepted that a lessee had a right to 'possession' which was an interest in the land that the lessee was entitled to protect against third parties." 
third parties, ${ }^{242}$ even if, as discussed above, equity would issue an injunction to prevent revocation by the original contracting party. ${ }^{243}$ But in a series of cases, with Lord Denning at the fore, some attempt, ultimately unsuccessful, was made to fashion something described as a licence coupled with an equity so that third parties were bound. ${ }^{244}$ In the leading case of Errington v. Errington, a man bought a house and allowed his son and daughter-in-law to occupy it, promising that if they paid the mortgage instalments he would transfer the ownership to them once the mortgage was paid in full. They made the payments, but after the son moved out and the father died, the latter's widow sought to evict her daughter-in-law, even though she continued to make the payments. Lord Denning held that a finding that the couple were no more than tenants at will would be "contrary to the justice of the case," and concluded instead that they were licensees with "a contractual right, or at any rate, an equitable right to remain" so long as the payments were made. ${ }^{245}$ The contractual licence, coupled with the equity, had "a force and validity" of its own, with the result that "[n]either the licensor nor anyone who claims through him can disregard the contract except a purchaser for value without notice."246

The principle from Errington was applied in other English cases prior to its rejection by the House of Lords, ${ }^{247}$ and has also been employed in Canada. Freeborn v. Goodman ${ }^{248}$ concerned occupiers of suites in a co-operative apartment building who had signed agreements which were not leases but which gave them an exclusive right to occupy. These agreements purported to "sell" them occupation rights terminable only on default of meeting their obligations to the owner of the building. When the mortgage held by the owner was foreclosed, the mortgagee wanted to evict them. The Supreme Court of Canada held that the occupiers' interests took precedence over any rights acquired by

This was certainly the traditional position: see King v. David Allen and Sons, [1916] 2 A.C. 54 (H.L.); H.W.R. Wade, "Licences and Third Parties" (1952) 68 L.Q. Rev. 337. For a more recent affirmation of the principle see Ashburn Anstalt v. W.J. Arnold \& Co., [1989] 1 Ch. I (C.A.). See also IDC Group v. Clark (1993), 65 P. \& C.R. 179 (C.A.); Northern \& Shell v. Condé Nast \& National Magazines Distributors, [1995] R.P.C. 117 (Ch.); S. Moriarty, "Licences and Land Law: Legal Principles and Public Policies" (1984) 100 L.Q. Rev. 376; G. Battersby, "Contractual and Estoppel Licences as Proprietary Interests in Land" (1991) 55 Conv. 36. See also Shaw, supra note 113 at 256-57, who notes that although "covenants touching and concerning the land will run against third parties, ... covenants not associated with a lease but granted instead as a part of a licence do not so run, not qualifying even as 'equities' for the purpose of applying priority rules."

See National Provincial Bank v. Ainsworth, [1965] A.C. 1175 (H.L.) [hereinafter Ainsworth] at 1253: "The fact that a contractual right can be specifically performed, or its breach prevented by injunction, does not mean that the right is any the less of a personal character or that a purchaser with notice is bound by it."

See especially Errington v. Errington, [1952] 1 K.B. 290 (C.A.) [hereinafter Errington]; see also National Provincial Bank v. Hastings Car Mart, [1964] 1 Ch. 665) (C.A.). Errington, ibid. at 296.

Ibid. at 299.

The rejection is usually traced to Ainsworth, supra note 243 . See especially In Sharpe, [1980] I All E.R. 198 (Ch.D.); DHN Food Distributors v. London Borough of Tower Hamlets, [1976] 3 All E.R. 462 (C.A.). For a discussion see A. Briggs, "Licences - Back to Basics" (1981) 45 Conv. 212. For an argument that licences can bind third parties, see P.N. Todd, "Estoppel Licences and Third Party Rights" (1981) 45 Conv. 347. 
foreclosure. Ritchie J.'s majority judgment referred to, although it did not adopt, Errington, and also noted that "the facts of the present case ... [were] more favourable to the appellants [occupiers] than they were to the licensees" in Errington. ${ }^{249}$ Then, in a description which closely matches the idea of a licence coupled with an equity, he held that the occupiers had "acquired by way of purchase ... an equitable title to the exclusive right of occupancy of their respective suits and to quiet possession thereof so long as they ... were not in default under the terms of the agreement." ${ }^{250}$ We can find no other Canadian case applying this idea, although there is also no case rejecting it. Its uncertain status is probably the result of the acceptance and substantial expansion of the restitutionary constructive trust in Canadian law; many of the kinds of situations which might have attracted the licence coupled with an equity argument are now dealt with through that doctrine.

Assuming that Lord Denning's notion of a licence enforceable against third parties has not been rejected in Canada (and indeed we would make the same argument even if it has), we suggest that it is time to seriously revisit the concept in this context. The tenant, a contractual licencee, could be regarded as having an equitable interest in the duration of the term. That equity, coupled with the licence, would be sufficient to bind third parties with notice.

To the extent that the problem we are here dealing with is the product of the privity rule, it should also be noted that that rule itself is being eroded. Doubts about its applicability in situations analogous to this can be found as far back as the mid-nineteenth century; ${ }^{251}$ one Canadian province and certain other common law jurisdictions have abolished it; ${ }^{252}$ and the Supreme Court of Canada has endorsed the idea that privity may be relaxed where "commercial reality and justice" demand. ${ }^{253}$ It is hard to think of an

249

250

Ibid. at 406.

Ibid.

See De Mattos v. Gibson (1858), 4 De G \& J. 276, 45 E.R. 108 (Ch.) [hereinafter De Mattos]. Here the buyer of a ship who had notice of a charterparty agreement with a third party was held to be bound by it. In coming to this conclusion, Knight Bruce L.J. stated in part, at 110: "Reason and justice seem to prescribe that ... where a man, by gift or purchase, acquires property from another, with knowledge of a previous contract ... made by him with a third person, to use and employ the property, ... the acquirer shall not, to the material damage of the third person, in opposition to the contract and inconsistently with it, use and employ the property in a manner not allowable to the giver or seller."

New Brunswick has abolished the rule: see Law Reform Act, S.N.B. 1993, c. L-1.2, s. 4(1). Privity has been abolished or modified in New Zealand (Contracts (Privity) Act 1982 (N.Z.) No. 132), Western Australia (Property Law Act 1969, (W.A.) No. 32, s. 11), and Queensland (Property Law Act 1974, (Qld) No. 76, s. 55).

London Drugs v. Kuehne \& Nagel International (1992), 97 D.L.R. (4th) 261 (S.C.C.) at 359-60. In full, Iacobucci J. stated: "Law reformers, commentators and judges have pointed out the gaps that sometimes exist between contract theory on the one hand, and commercial reality and justice on the other.... While these comments may not, in themselves, justify doing away with the doctrine of privity, they none the less give a certain context to the principles that this court is now dealing with. This context clearly supports in my view some type of reform or relaxation to the law relating to third party beneficiaries." This exception to the privity rule has been confirmed in Fraser River Pile \& Dredge v. Can-Dive Services (1999), 176 D.L.R. (4th) 257 at 269 (S.C.C.) at 273, in which Iacobucci J. referred to the "commercial reality and justice" exception as the "principled exception 
instance where both commercial reality and justice would more strongly demand the fashioning of a remedy than the one with which we are dealing. More importantly, as one Canadian commentator has argued, the "theoretical deficiencies"with it are "less obvious" than its institutional rejection would make it seem. ${ }^{254}$ This is presumably an allusion to the fact that, while the common law resists the creation of new kinds of estates or other interests in land, ${ }^{25 s}$ it has been prepared to do so when appropriate. We are not suggesting that all contractual licences be made enforceable in this way. Rather, we are arguing that in a situation where the tenant would meet the requirements for specific enforcement against the original contracting landlord discussed above, he or she could do so against a successor. The only exception would be, as with all equitable interests, where the third party was a bona fide purchaser for value without notice.

A striking analogy can perhaps be drawn here with restrictive covenants. Before the mid-nineteenth century such a covenant would not bind a successor-in-title. But in Tulk v. Moxhay it was said to be inequitable for a purchaser with notice of the restriction, and who had presumably bought the land for a price that reflected the restriction, to disregard it thereafter. The Court held that "if an equity is attached to the property by the owner, no one purchasing with notice of that equity can stand in a different situation from the party from whom he purchased." 256 Subsequent cases, of course, added a variety of other requirements for the enforcement of restrictive covenants against third party purchasers of burdened land, ${ }^{257}$ but that does not concern us. The point for our purposes is that the same equitable principle could easily be adapted to contractual licensees occupying for a term. ${ }^{258}$ Indeed there ought to be less concern about commercial leases than restrictive covenants in this regard, for they bind the land for much less time. Thus if the purchaser of the landlord's interest bought with notice, and if the tenant would otherwise be able to enforce the term against the original landlord, there is every reason to expand that enforceability. There would be even more reason to do so if the tenant had been able to bargain for a covenant by the original landlord that he or she would bind assignees to the terms of the contract. In this way, any lingering doubts about the

to the privity of contract doctrine." See also Trudel v. Clairol Inc. of Canada (1974), 54 D.L.R. (3d) 399 (S.C.C.), where a third party was restrained from selling a product contrary to an agreement between a manufacturer and its wholesalers. On the erosion of the privity rule, see generally Waddams, supra note 185 at 193-207. Ziff, supra note 32 at 284.

The classic statement of the principle is Keppell v. Bailey (1834), 2 My. \& K. 517, 39 E.R. 1042. For a discussion see B. Rudden, "Economic Theory v. Property Law: The Numerus Clausus Problem" in J. Eekelaar \& J. Bell, eds., Oxford Essays in Jurisprudence (Oxford: Oxford University Press, 1987) at 239.

(1848), 2 Ph. 774 at 778, 41 E.R. 1143 at 1144 (Ch.).

These are the requirements that there be a dominant and servient tenement, that the restriction be negative in substance, and that the covenant touch and concern the land of the covenantee: see Ziff, supra note 32 at $369-71$.

Interestingly, the connection between the basic principle underlying Tulk v. Moxhay, and the doctrine enunciated in De Matlos, supra note 251, and relied on here, was recognized in Lord Strathcona Steamship Co. v. Dominion Coal Co., [1926] A.C. 108 at 117-118 (P.C.). The similarities are also noted and discussed in an article principally concerned with subsequent accretions to the $T u l k$ principle: see S. Gardner, "The Proprietary Effect of Contractual Obligations under Tulk v. Moxhay and De Mattos v. Gibson" (1982) 98 L.Q. Rev. 279. 
durability of the rights of the tenant (or, more properly, licensee for a term) would be resolved.

\section{CONCLusion}

This article has been concerned with the legal nature of the commercial lease, in particular with whether it should be seen as belonging to a contract or a property regime - or, perhaps, to both. Section II, a largely descriptive section, demonstrated that to some extent judicial decisions have already moved the lease away from its traditional property basis and have, at the very least, undermined the idea that it is beyond the reach of contractual doctrines. The result, we argued, has been the creation of a hybrid of classical lease and contract rules, what we termed "partial contractualization." In Section III we moved from the descriptive to the prescriptive, arguing that this hybrid was conceptually confusing, out of step with the reality of the modern commercial lease, and, to the extent that it contained property elements, the product simply of contingent historical circumstances. Ultimately, we argued, the commercial lease should belong entirely to the world of contract law. That is, we advocated complete contractualization.

Section IV examined what a completely contractualized lease would look like. It would, of course, not be a "lease" at all, but a contractual right to occupy and use land - a licence. In general, a move from lease to licence would, in altering the unique legal rules that now govern leases, bring beneficial results. We recognized, however, that complete contractualization would destroy a necessary and valuable attribute of the current conception of the lease: the tenant's security of tenure in the term. Yet, we argue, while this may be protected against both the landlord and any successors-in-title to the landlord, because the lease is seen as a conveyance, it may also continue to be protected after complete contractualization. There are concepts and devices available within the law to take the place of the concept of the lease as an estate; these include specific performance, equitable estoppel, and contractual licence doctrines. Our point here is that security of tenure can still be assured to the tenant after complete contractualization; thus if that change is otherwise desirable, we should not allow security concerns to block general reform. In short, the complete assimilation of the lease within contract law is both desirable and, with a little imagination, possible. 